\title{
Effect of the catalyst preparation method on the performance of Ni-supported catalysts for the synthesis of saturated amines from nitrile hydrogenation
}

\author{
D. J. Segobia, A. F. Trasarti, C. R. Apesteguía* \\ Catalysis Science and Engineering Research Group (GICIC), INCAPE, UNL-CONICET, CCT Conicet- Paraje El Pozo, (3000) Santa Fe, Argentina
}

\section{A R T I C L E I N F O}

\section{Article history:}

Received 3 October 2018

Accepted 12 October 2018

Published 5 November 2019

\section{Keywords:}

Nitrile hydrogenation

Saturated amines

Ni-supported catalysts

Ni-phyllosilicates

Catalyst preparation

\begin{abstract}
A B S T R A C T
The liquid-phase hydrogenation of butyronitrile to saturated amines was studied on silica-supported $\mathrm{Ni}$ catalysts prepared by either incipient-wetness impregnation $\left(\mathrm{Ni} / \mathrm{SiO}_{2}-\mathrm{I}\right)$ or ammonia $\left(\mathrm{Ni} / \mathrm{SiO}_{2}-\mathrm{A}\right)$ methods. $\mathrm{A} \mathrm{Ni} / \mathrm{SiO}_{2}-\mathrm{Al}_{2} \mathrm{O}_{3}-\mathrm{I}$ sample was also used. $\mathrm{Ni} / \mathrm{SiO}_{2}$-I was a non-acidic catalyst containing large $\mathrm{Ni}^{0}$ particles of low interaction with the support, while $\mathrm{Ni} / \mathrm{SiO}_{2}-\mathrm{A}$ was an acidic catalyst due to the presence of $\mathrm{Ni}^{2+}$ species in Ni phyllosilicates of low reducibility. $\mathrm{Ni} / \mathrm{SiO}_{2}-\mathrm{I}$ formed essentially butylamine $(80 \%)$, and dibutylamine as the only byproduct. In contrast, $\mathrm{Ni} / \mathrm{SiO}_{2}-\mathrm{A}$ yielded a mixture of dibutylamine (49\%) and tributylamine (45\%), being the formation of butylamine almost completely suppressed. The selective formation of secondary and tertiary amines on $\mathrm{Ni} / \mathrm{SiO}_{2}-\mathrm{A}$ was explained by considering that butylamine is not release to the liquid phase during the reaction because it is strongly adsorbed on surface acid sites contiguous to $\mathrm{Ni}^{0}$ atoms, thereby favoring the butylimine/butylamine condensation to higher amines between adsorbed species.
\end{abstract}

(C) 2019, Dalian Institute of Chemical Physics, Chinese Academy of Sciences.

Published by Elsevier B.V. All rights reserved.

\section{Introduction}

Aliphatic amines are important chemicals widely used for the synthesis of pharmaceuticals, agrochemicals, bioactive compounds, polymers and dyes [1,2]. The liquid-phase hydrogenation of nitriles conducted at high hydrogen pressures in presence of metal catalysts is an important route to produce the corresponding saturated amines at industrial level. The reaction proceeds through consecutive hydrogenation/condensation steps forming a mixture of primary, secondary and tertiary amines. The most accepted reaction mechanism for nitrile hydrogenation to amines is based on the pioneer work of Sabatier and Senderens [3], Braun et al. [4], and others [5,6], and is illustrated in Fig. 1 for butyronitrile hydrogenation. Butyronitrile (BN) is initially converted to butylimine that is consecutively hydrogenated to $n$-butylamine
(BA). Butylimine is a highly reactive intermediate that interacts with $n$-butylamine to form 1-aminodibutylamine which gives by deamination the secondary imine, butylidene-butylamine (BBA), that is finally hydrogenated to dibutylamine (DBA). Similarly, butylimine may react with dibutylamine giving 1-aminotributylamine that after consecutive deamination and hydrogenation leads to the formation of tributylamine (TBA).

According to the reaction network of Fig. 1, butyronitrile forms initially BA that is then converted to DBA and TBA through consecutive condensation reactions. Frequently, high selectivity to a given amine is wanted in order to eliminate the cost of the product separation process. Thus, increasing research efforts have been devoted to gain fundamental knowledge on the selectivity of nitrile hydrogenation toward different amines $[7,8]$. Several papers have reported that the activity and selectivity of nitrile hydrogenation on met-

* Corresponding author. Tel: +54-342-4511370; E-mail: capesteg@fiq.unl.edu.ar

DOI: 10.1016/S1872-2067(18)63179-1 | http://www.sciencedirect.com/science/journal/18722067 | Chin. J. Catal., Vol. 40, No. 11 , November 2019 


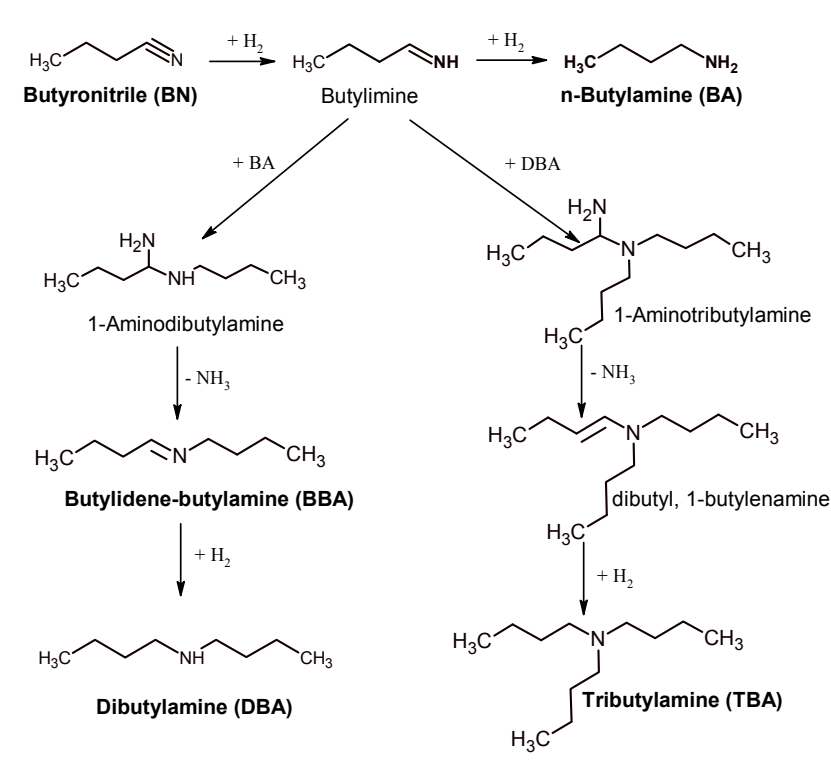

Fig. 1. Reaction scheme for the synthesis of amines from butyronitrile.

al-supported catalysts depend mainly on the nature of the metal $[9,10]$. For example, $\mathrm{Ni}$, Co and Ru show high selectivity towards the production of primary amines while noble metals such as Pt, Pd and Rh promote the formation of secondary and tertiary amines $[8,10,11]$. However, the reaction selectivity also depends on other parameters such as the support acid/base properties, the solvent nature and the catalyst preparation method. In previous works, we have thoroughly studied the effect of solvent on nitrile hydrogenation selectivity and activity using metal-supported catalysts [12-14]. The influence of support acidity on catalyst selectivity has also been investigated, but while some authors propose that the surface acidity favors the condensation reactions and is detrimental for the formation of primary amines $[15,16]$, others suggest that acidity has no influence on the reaction selectivity [17]. Finally, there are very few studies dealing with the effect of the preparation method of the catalyst on the reaction selectivity. The incipient wetness impregnation method has been used to prepare $\mathrm{Ni} / \mathrm{SiO}_{2}$ catalysts highly selective for obtaining primary amines from nitrile hydrogenation [10]. In this method, the $\mathrm{pH}$ of the synthesis environment is fixed by the solution of the precursor salt. In this way, when silica is impregnated with a solution of nickel nitrate, the metal is deposited at $\mathrm{pH}$ between 5 and 6 . Catalysts prepared by incipient-wetness impregnation typically presents large metal particles and weak metal-support interactions. Other preparation procedures such as ion-exchange, deposition-precipitation, and the ammonia method have been employed to obtain well-dispersed $\mathrm{Ni} / \mathrm{SiO}_{2}$ catalysts $[18,19]$. In particular, the ammonia method was developed to prepare $\mathrm{Ni} / \mathrm{SiO}_{2}$ catalysts exhibiting uniform dispersion of small nickel particles at relatively high metal loadings [20,21]. Essentially, the ammonia method consists of contacting silica with $\mathrm{Ni}(\mathrm{II})$ ammonia solutions prepared by adding concentrated solutions of $\mathrm{NH}_{4} \mathrm{OH}$ to an aqueous solution of nickel nitrate at $\mathrm{pH}$ between 9 and 11. Cation complexes such as $\left[\mathrm{Ni}\left(\mathrm{NH}_{3}\right)_{6}\right]^{2+}$ are formed and exchanged with acidic protons on the support sur- face.

In the present work, we studied the effect of the catalyst preparation method on the performance of $\mathrm{Ni} / \mathrm{SiO}_{2}$ for the hydrogenation of nitriles using butyronitrile as model molecule. $\mathrm{Ni} / \mathrm{SiO}_{2}$ catalysts were prepared by both the incipient wet impregnation and the ammonia methods. Results show that $\mathrm{Ni} / \mathrm{SiO}_{2}$ prepared by incipient wet impregnation forms selectively butylamine (primary amine) whereas prepared by the ammonia method produces essentially dibutylamine (secondary amine) and tributylamine (tertiary amine), thereby indicating that the reaction selectivity may be tuned by selecting the proper catalyst preparation method.

\section{Experimental}

\subsection{Catalyst preparation}

Nickel-on-silica catalysts were prepared by incipient-wetness impregnation $\left(\mathrm{Ni} / \mathrm{SiO}_{2}-\mathrm{I}\right)$ and ammonia $\left(\mathrm{Ni} / \mathrm{SiO}_{2}-\mathrm{A}\right)$ methods. $\mathrm{Ni} / \mathrm{SiO}_{2}-\mathrm{I}(3.5 \% \mathrm{Ni})$ was obtained by impregnating at room temperature a commercial $\mathrm{SiO}_{2}$ sample (Davisil Grade 62, $\left.300 \mathrm{~m}^{2} / \mathrm{g}\right)$ with a aqueous solution $(0.33 \mathrm{~mol} / \mathrm{L})$ of Ni nitrate $\left(\mathrm{Ni}\left(\mathrm{NO}_{3}\right)_{2} \cdot 6 \mathrm{H}_{2} \mathrm{O}\right.$, Fluka 98\%). Then, the impregnated sample was dried for $12 \mathrm{~h}$ at $373 \mathrm{~K}$ and calcined in air at $673 \mathrm{~K}$ for $2 \mathrm{~h}$. Before performing the catalytic tests, $\mathrm{Ni} / \mathrm{SiO}_{2}$-I was reduced in $\mathrm{H}_{2}$ for $1 \mathrm{~h}$ at $673 \mathrm{~K}$. Ni/SiO $2-\mathrm{A}(3.2 \% \mathrm{Ni})$ was prepared by adding $\mathrm{NH}_{4} \mathrm{OH} 28 \%$ to a suspension of $5 \mathrm{~g}$ of dry support in $80 \mathrm{~mL}$ of a solution $0.5 \mathrm{~mol} / \mathrm{L}$ of $\mathrm{Ni}\left(\mathrm{NO}_{3}\right)_{2} .6 \mathrm{H}_{2} \mathrm{O}$ (Anedra) until $\mathrm{pH}=10$ to generate the adsorbed nickel hexamine complex. The green solid was then separated by filtration, washed with a $\mathrm{NH}_{4} \mathrm{OH}$ solution $(\mathrm{pH}=10)$ and dried for $12 \mathrm{~h}$ at $373 \mathrm{~K}$. Before performing the catalytic tests, $\mathrm{Ni} / \mathrm{SiO}_{2}-\mathrm{A}$ was reduced in $\mathrm{H}_{2}$ for $1 \mathrm{~h}$ at $823 \mathrm{~K}$. A Ni/ $\mathrm{SiO}_{2}-\mathrm{Al}_{2} \mathrm{O}_{3}-\mathrm{I}(4.1 \% \mathrm{Ni}$ ) sample was prepared by incipient-wetness impregnation following the same procedure detailed above for preparing $\mathrm{Ni} / \mathrm{SiO}_{2}-\mathrm{I}$ and using a commercial $\mathrm{SiO}_{2}-\mathrm{Al}_{2} \mathrm{O}_{3}$ support (Sigma-Aldrich Grade $135,467 \mathrm{~m}^{2} / \mathrm{g}$, Si $/ \mathrm{Al}=$ 6.7). This sample was reduced in $\mathrm{H}_{2}$ at $773 \mathrm{~K}$ for $1 \mathrm{~h}$ prior to carry out the catalytic tests.

\subsection{Catalyst characterization}

BET surface areas ( $\left.S_{\mathrm{BET}}\right)$ were measured by $\mathrm{N}_{2}$ physisorption at $77 \mathrm{~K}$ in a Micromeritics Accusorb 2100E sorptometer and the nickel loadings were determined by inductively coupled plasma atomic emission spectroscopy (ICP-AES), using a Perkin-Elmer Optima 2100 unit. The metal dispersion $\left(D_{\mathrm{Ni}}\right.$, surface $\mathrm{Ni}$ atoms/total $\mathrm{Ni}$ atoms) was determined by $\mathrm{H}_{2}$ chemisorption performing volumetric adsorption experiments at room temperature (RT) in a conventional vacuum unit. Catalysts were reduced in $\mathrm{H}_{2}$ at the same conditions used to activate them prior to catalytic tests, and then outgassed for $2 \mathrm{~h}$ prior to perform gas chemisorption experiments. The hydrogen uptake was determined using the double isotherm method as detailed elsewhere [22]. $D_{\mathrm{NI}}$ was obtained based only on the amount of nickel reducible to metallic nickel; that is, the amount of unreducible nickel was assumed to interact so strongly with the support that it would not be part of the metal particles. A stoi- 
chiometric atomic ratio $\mathrm{H} / \mathrm{Ni}_{\mathrm{s}}=1$, where $\mathrm{Ni}_{\mathrm{s}}$ implies a $\mathrm{Ni}$ atom on surface, was used to calculate $D_{\mathrm{Ni}}$. Average Ni crystallite sizes were determined by assuming cubic particles and a cross-sectional area of $0.065 \mathrm{~nm}^{2}$ for a $\mathrm{Ni}$ atom [23].

The temperature programmed reduction (TPR) experiments of calcined samples were performed in a Micromeritics AutoChem II 2920 equipped with a TCD detector, under a 5\% $\mathrm{H}_{2} / \mathrm{Ar}$ gaseous mixture at $60 \mathrm{~cm}^{3} / \mathrm{min}$ STP. Samples were heated from RT to $1073 \mathrm{~K}$ at $10 \mathrm{~K} / \mathrm{min}$.

The calcined and reduced $\mathrm{Ni}$ samples were analyzed by X-ray diffraction (XRD) and X-ray photoelectron spectroscopy (XPS) techniques. Prior to analysis, the reduced samples were passivated before exposing to air by treating them at RT in a $\mathrm{O}_{2}(2 \%) / \mathrm{He}$ mixture for $30 \mathrm{~min}$. The solid structure and crystal size of calcined and reduced-passivated samples was determined by XRD in the range of $2 \theta=10^{\circ}-70^{\circ}$ using a Shimadzu XD-D1 diffractometer and Ni-filtered $\mathrm{Cu} K_{\alpha}$ radiation. Mean crystallite size were calculated using the Scherrer equation.

XPS analyses were performed in a SPECS multianalysis device, equipped with a dual $\mathrm{Mg} / \mathrm{Al} \mathrm{X}$-ray source and a PHOIBOS 150 hemispherical analyzer. Spectra were obtained under ultra-high vacuum conditions, using the monochromatic Mg $K_{\alpha}$ radiation with a $200-\mathrm{W}$ source power and a fixed analyzer pass energy of $30 \mathrm{eV}$. The pressure in the analyzing chamber was lower than $5.10^{-7} \mathrm{~Pa}$. The spectral region corresponding to $\mathrm{Ni}$ $2 p$ core level was analyzed for each sample. Casa XPS software (Casa Software Ltd., UK) was used for data treatment. The spectra were corrected by referencing the XPS C $1 s$ binding energy (284.6 eV).

Acid site densities were determined by temperature-programmed desorption (TPD) of $\mathrm{NH}_{3}$ preadsorbed at 373 K. Samples (200 mg) were exposed to a $1 \% \mathrm{NH}_{3} / \mathrm{He}$ stream (60 $\mathrm{cm}^{3} / \mathrm{min}$ ) for $1 \mathrm{~h}$. Weakly adsorbed $\mathrm{NH}_{3}$ was removed under a $60 \mathrm{~cm}^{3} / \mathrm{min}$ flow of He at $373 \mathrm{~K}$ during $1 \mathrm{~h}$. Finally, the temperature was increased at $10 \mathrm{~K} / \mathrm{min}$ and the $\mathrm{NH}_{3}$ concentration in the effluent was followed by mass spectrometry (MS) in a Baltzers Omnistar unit.

The nature and strength of surface acid sites were determined by Fourier transform infrared spectroscopy (FTIR) in a Shimadzu FTIR-8101M spectrophotometer using pyridine as a probe molecule. Samples were ground to a fine powder and pressed into wafers $(20-40 \mathrm{mg})$ at $5 \mathrm{ton} / \mathrm{cm}$. The discs were mounted in a quartz sample holder and transferred to an inverted T-shaped Pyrex cell equipped with $\mathrm{CaF}_{2}$ windows. Samples were outgassed in vacuum at $623 \mathrm{~K}$ during $4 \mathrm{~h}$ and then a background spectrum was recorded after being cooled down to RT. Data were obtained at RT after admission of pyridine and degassing at 423,573 , and $723 \mathrm{~K}$ for $30 \mathrm{~min}$. Spectra were recorded by subtracting the background spectrum. The spectral resolution was $2 \mathrm{~cm}^{-1}$ and the spectra are the average of 50 scans.

The butylamine interactions with the catalysts were studied by temperature-programmed desorption (TPD) of butylamine preadsorbed at RT. Calcined samples (200 $\mathrm{mg}$ ) were reduced between 673 and $873 \mathrm{~K}$ for $1 \mathrm{~h}$ and then cooled down to RT. Afterwards, a He stream was bubbled through the reagent to saturate the gaseous stream with butylamine vapor and the sample was contacted to this stream for $1 \mathrm{~h}$. The effluent composition was monitored by mass spectrometry (MS) in a Baltzers Omnistar unit. Weakly adsorbed butylamine was removed by flushing with $\mathrm{He}\left(60 \mathrm{~cm}^{3} / \mathrm{min}\right)$ at RT for $1 \mathrm{~h}$. Temperature was then increased at $10 \mathrm{~K} / \mathrm{min}$ and the composition of the reactor effluent was measured by mass spectrometry.

\subsection{Catalytic activity}

Catalytic tests for the liquid-phase hydrogenation of butyronitrile (Aldrich, > 99\%) were performed in a stainless-steel autoclave at 13 bar $\left(\mathrm{H}_{2}\right)$ and $373 \mathrm{~K}$, using ethanol (Cicarelli, ACS) as solvent. The reactor was loaded with $150 \mathrm{~mL}$ of solvent, $1.0 \mathrm{~g}$ of catalyst, $3 \mathrm{~mL}$ of butyronitrile, and $1 \mathrm{~mL}$ of $n$-dodecane (Aldrich $>99 \%$ ) as internal standard. Samples were activated ex-situ in hydrogen for $1 \mathrm{~h}$ at $673 \mathrm{~K}\left(\mathrm{Ni} / \mathrm{SiO}_{2}-\mathrm{I}\right)$, $773 \mathrm{~K}\left(\mathrm{Ni} / \mathrm{SiO}_{2}-\mathrm{Al}_{2} \mathrm{O}_{3}-\mathrm{I}\right)$ and $823 \mathrm{~K}\left(\mathrm{Ni} / \mathrm{SiO}_{2}-\mathrm{A}\right)$, and loaded under inert atmosphere to the reactor. The reaction mixture was stirred at $800 \mathrm{rpm}$ and heated gradually to the reaction temperature; the $\mathrm{H}_{2}$ pressure was then rapidly increased to 13 bar.

The composition of the reaction mixture was analyzed by ex-situ gas chromatography using an Agilent 6850 GC chromatograph equipped with flame ionization detector, temperature programmer and a $50 \mathrm{~m} \mathrm{HP}-1$ capillary column $(50 \mathrm{~m} \times$ $0.32 \mathrm{~mm}$ ID, $1.05 \mu \mathrm{m}$ film). Samples from the reaction system were taken by using a loop under pressure in order to avoid flashing. Data were collected every 15-40 min for 550-700 min. Interparticle and intraparticle diffusional limitations were verified as negligible. Conversion of butyronitrile was calculated as $X_{\mathrm{BN}}=\left(C_{\mathrm{BN}}^{0}-C_{\mathrm{BN}}\right) / C_{\mathrm{BN}}^{0}$, where $C_{\mathrm{BN}}^{0}$ is the initial concentration of butyronitrile and $C_{\mathrm{BN}}$ is the concentration of butyronitrile at reaction time $t$. Selectivities $\left(S_{j}\right.$, mol of product $j / \mathrm{mol}$ of butyronitrile reacted) were calculated as $S_{\mathrm{j}}=C_{\mathrm{j}} v_{\mathrm{BN}} /\left(C_{\mathrm{BN}}^{0}-C_{\mathrm{BN}}\right) / v_{\mathrm{j}}$ where $v_{\mathrm{BN}}$ and $v_{\mathrm{j}}$ are the stoichiometric coefficients of butyronitrile and product $j$, respectively. Yields $\left(Y_{\mathrm{j}}\right.$, mol of product $j /$ mol of butyronitrile fed) were calculated as $Y_{\mathrm{j}}=S_{\mathrm{j}} X_{\mathrm{BN}}$.

\section{Results and discussion}

\subsection{Catalyst characterization}

The metal loading and the physicochemical properties of the catalyst are given in Table 1 . Specific surface areas of $\mathrm{Ni} / \mathrm{SiO}_{2}-\mathrm{I}$ $\left(290 \mathrm{~m}^{2} / \mathrm{g}\right)$ and $\mathrm{Ni} / \mathrm{SiO}_{2}-\mathrm{A}\left(285 \mathrm{~m}^{2} / \mathrm{g}\right)$ were slightly lower than that of $\mathrm{SiO}_{2}$ support $\left(300 \mathrm{~m}^{2} / \mathrm{g}\right)$ while $\mathrm{SET}_{\mathrm{BET}}$ of $\mathrm{Ni} / \mathrm{SiO}_{2}-\mathrm{Al}_{2} \mathrm{O}_{3}-\mathrm{I}$ $\left(460 \mathrm{~m}^{2} / \mathrm{g}\right)$ was like that of $\mathrm{SiO}_{2}-\mathrm{Al}_{2} \mathrm{O}_{3}\left(467 \mathrm{~m}^{2} / \mathrm{g}\right)$. These results show that there is not any significant blockage of the support porous structure by the addition of the metal. Fig. 2(A) shows the XRD patterns obtained for calcined samples. $\mathrm{Ni} / \mathrm{SiO}_{2}-\mathrm{I}$ and $\mathrm{Ni} / \mathrm{SiO}_{2}-\mathrm{Al}_{2} \mathrm{O}_{3}-\mathrm{I}$ presented a single phase of $\mathrm{NiO}$ (ASTM 4-835). The NiO particle sizes were 12 and $11 \mathrm{~nm}$ for $\mathrm{Ni} / \mathrm{SiO}_{2}-\mathrm{I}$ and $\mathrm{Ni} / \mathrm{SiO}_{2}-\mathrm{Al}_{2} \mathrm{O}_{3}-\mathrm{I}$, respectively (Table 1 ). The $\mathrm{Ni} / \mathrm{SiO}_{2}-\mathrm{A}$ diffractogram presented diffraction signals that based in previous results $[24,25]$ may be associated with the presence of $\mathrm{Ni}^{2+}$ ions in Ni-containing phyllosilicates (layered nickel silicates) widely dispersed on the surface. Ni phyllosili- 
Table 1

Characterization of the catalysts used in this work.

\begin{tabular}{|c|c|c|c|c|c|c|c|c|}
\hline Catalyst & Treatment & $\begin{array}{c}\text { Ni loading a } \\
(\%)\end{array}$ & $\begin{array}{c}S_{\mathrm{BET}} \\
\left(\mathrm{m}^{2} / \mathrm{g}\right)\end{array}$ & $\begin{array}{c}\text { NiO particle size }{ }^{b} \\
(\mathrm{~nm})\end{array}$ & $\begin{array}{c}\mathrm{Ni}^{0} \text { particle size }{ }^{\mathrm{b}} \\
(\mathrm{nm})\end{array}$ & $\begin{array}{l}D_{\mathrm{Ni}}{ }^{c} \\
(\%)\end{array}$ & $\begin{array}{c}\mathrm{Ni}^{0} \text { particle size } \\
(\mathrm{nm})\end{array}$ & $\begin{array}{c}\text { Reduction degree } \\
(\%)\end{array}$ \\
\hline \multirow[t]{2}{*}{$\mathrm{Ni} / \mathrm{SiO}_{2}-\mathrm{I}$} & Calcined $^{\mathrm{d}}$ & 3.5 & 290 & 12 & - & - & - & - \\
\hline & Reduced e & - & - & - & 14 & 3 & 27.5 & 100 \\
\hline \multirow[t]{2}{*}{$\mathrm{Ni} / \mathrm{SiO}_{2}-\mathrm{Al}_{2} \mathrm{O}_{3}-\mathrm{I}$} & Calcined d & 4.1 & 460 & 11 & - & - & - & 一 \\
\hline & Reduced $^{\mathrm{f}}$ & - & - & - & 13 & 5 & 16.5 & 95 \\
\hline \multirow[t]{2}{*}{$\mathrm{Ni} / \mathrm{SiO}_{2}-\mathrm{A}$} & Calcined d & 3.2 & 285 & - & 一 & - & 一 & 一 \\
\hline & Reduced $\mathrm{g}$ & - & - & - & 8 & 25 & 3.3 & 55 \\
\hline
\end{tabular}

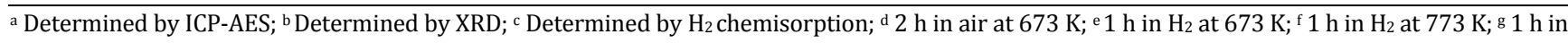
$\mathrm{H}_{2}$ at $823 \mathrm{~K}$.
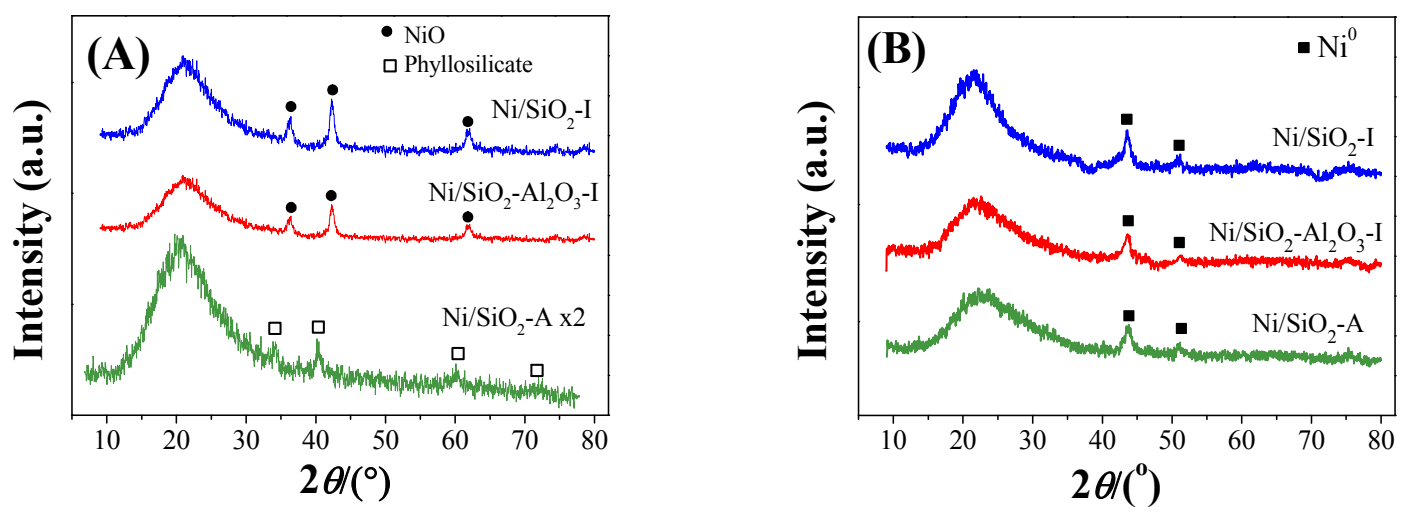

Fig. 2. X-ray diffractograms of calcined (A) and reduced (B) Ni samples.

cates consist of brucite-type layers containing $\mathrm{Ni}^{2+}$ in octahedral coordination and one or two sheets of tetrahedral $\mathrm{SiO}_{4}$ units [26,27]. The sandwich-like structures of Ni phyllosilicates with formula $\mathrm{Ni}_{3} \mathrm{Si}_{4} \mathrm{O}_{12} \mathrm{H}_{2}$ (Ni 2:1 PS) and $\mathrm{Ni}_{3} \mathrm{Si}_{2} \mathrm{O}_{5}(\mathrm{OH})_{4}(\mathrm{Ni}$ 1:1 PS) have been detailed described elsewhere $[28,29]$.

After reduction for $1 \mathrm{~h}$ at $673 \mathrm{~K}\left(\mathrm{Ni} / \mathrm{SiO}_{2}-\mathrm{I}\right), 773 \mathrm{~K}$ $\left(\mathrm{Ni} / \mathrm{SiO}_{2}-\mathrm{Al}_{2} \mathrm{O}_{3}-\mathrm{I}\right)$ and $823 \mathrm{~K}\left(\mathrm{Ni} / \mathrm{SiO}_{2}-\mathrm{A}\right)$ the three samples presented only a single crystalline phase of metallic Ni (Fig. 2(B)). No diffraction signals corresponding to Ni-phyllosilicate structures were detected in reduced $\mathrm{Ni} / \mathrm{SiO}_{2}-\mathrm{A}$. The $\mathrm{Ni}^{0}$ crystallite sizes as determined by Scherrer equation are included in Table 1 and show that $\mathrm{Ni}^{0}$ particles on $\mathrm{Ni} / \mathrm{SiO}_{2}$-A were smaller than on samples prepared by wet impregnation.

Fig. 3 shows the TPR profiles of calcined samples. In the case of $\mathrm{Ni} / \mathrm{SiO}_{2}$-I, a single consumption peak with a maximum at 653 $\mathrm{K}$ was observed. According to literature [30,31], this peak arises from the reduction of large particles of bulk NiO interacting weakly with the silica support. The TPR profile of $\mathrm{Ni} / \mathrm{SiO}_{2}-\mathrm{Al}_{2} \mathrm{O}_{3}-\mathrm{I}$ exhibited a broad reduction band that was well deconvoluted into peaks centered at 642 and $763 \mathrm{~K}$, respectively (Fig. 3). Other authors have also reported that the TPR curves of $\mathrm{Ni} / \mathrm{SiO}_{2}-\mathrm{Al}_{2} \mathrm{O}_{3}$ catalysts prepared by wet impregnation present two superimposed reductions peaks [32-34]. The low-temperature at $642 \mathrm{~K}$ corresponds to the direct reduction of $\mathrm{NiO}$ to metallic nickel, while the high-temperature peak can be assigned to the reduction of $\mathrm{Ni}^{2+}$ species interacting strongly with the support, probably formed by partial cation exchange with the support during the impregnation [32,34]. Finally, the TPR profile of $\mathrm{Ni} / \mathrm{SiO}_{2}-\mathrm{A}$ showed three peaks at 657,728 and 823 , respectively: the first small peak was assigned to the re- duction of NiO particles, while the second and third one was attributed to the reduction of $\mathrm{Ni}^{+2}$ compounds that interact strongly with the support in the form of phyllosilicate-type compounds [35,36].

In order to establish the reduction degree (RD) of our Ni-supported samples at the beginning of the catalyst tests, we performed additional TPR experiments using the Ni samples reduced in $\mathrm{H}_{2}$ at the same conditions employed for activated them prior to catalytic tests; i.e. samples $\mathrm{Ni} / \mathrm{SiO}_{2}-\mathrm{I}$, $\mathrm{Ni} / \mathrm{SiO}_{2}-\mathrm{Al}_{2} \mathrm{O}_{3}-\mathrm{I}$ and $\mathrm{Ni} / \mathrm{SiO}_{2}-\mathrm{A}$ were reduced for $1 \mathrm{~h}$ at 673,773 and $823 \mathrm{~K}$, respectively, and then characterized by TPR. Results are reported in Table 1 . The $\mathrm{RD}$ values for $\mathrm{Ni} / \mathrm{SiO}_{2}-\mathrm{I}$ and $\mathrm{Ni} / \mathrm{SiO}_{2}-\mathrm{Al}_{2} \mathrm{O}_{3}-\mathrm{I}$ were $100 \%$ and $95 \%$, respectively, thereby showing that $\mathrm{Ni}$ was almost completely reduced to $\mathrm{Ni}^{0}$ for the

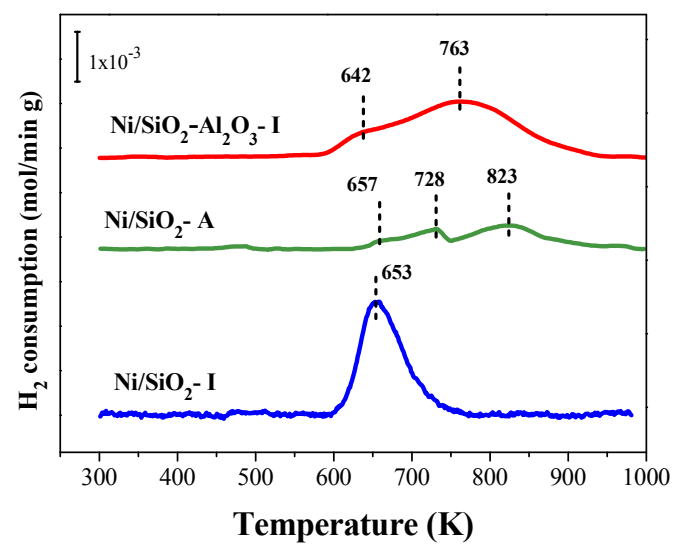

Fig. 3. TPR profiles of calcined samples. 
samples prepared by wet impregnation. In contrast, RD was only $55 \%$ for $\mathrm{Ni} / \mathrm{SiO}_{2}-\mathrm{A}$, thereby indicating that a significant part of nickel remained oxidized in Ni-phyllosilicate structures after the sample reduction at $823 \mathrm{~K}$. This is in agreement with previous work showing that reduction temperatures higher than $973 \mathrm{~K}$ are required to completely reduce Ni-containing phyllosilicates [24,37]. In summary, results from Fig. 3 and Table 1 show that the sample reducibility follows the order $\mathrm{Ni} / \mathrm{SiO}_{2}-\mathrm{I}>\mathrm{Ni} / \mathrm{SiO}_{2}-\mathrm{Al}_{2} \mathrm{O}_{3}-\mathrm{I}>>\mathrm{Ni} / \mathrm{SiO}_{2}-\mathrm{A}$.

The chemical state of surface Ni species was investigated by XPS and the results are presented in Fig. 4 and Table 2. The Ni $2 p_{3 / 2}$ XPS spectra for calcined $\mathrm{Ni} / \mathrm{SiO}_{2}-\mathrm{I}$ and $\mathrm{Ni} / \mathrm{SiO}_{2}-\mathrm{Al}_{2} \mathrm{O}_{3}-\mathrm{I}$ samples showed a $\mathrm{Ni} 2 p_{3 / 2}$ signal at $855.7 \mathrm{eV}$ (Fig. 4(A)) that has been assigned to $\mathrm{NiO}[38,39]$; this assignment is supported by the fact that the BE value of the satellite peak is $6.1 \mathrm{eV}$ higher than $\mathrm{Ni} 2 p_{3 / 2}$ primary line (Table 2) [40]. In the case of $\mathrm{Ni} / \mathrm{SiO}_{2}-\mathrm{A}$, the main peak of $\mathrm{Ni} 2 p_{3 / 2}$ was shifted to $857.7 \mathrm{eV}$, which reflects the formation of $\mathrm{Ni}$ phyllosilicate-type compounds $[40,41]$. The surface analysis of $\mathrm{Ni} / \mathrm{SiO}_{2}-\mathrm{I}$ and $\mathrm{Ni} / \mathrm{SiO}_{2}-\mathrm{Al}_{2} \mathrm{O}_{3}$-I reduced for $1 \mathrm{~h}$ at 673 and $773 \mathrm{~K}$, respectively, is presented in Fig. 4(B) and shows that the Ni $2 p_{3 / 2}$ spectra exhibit a peak at $853.0 \mathrm{eV}$, which is indicative of metallic $\mathrm{Ni}^{0}$ $[40,42]$. Ni/SiO 2 -A reduced for $1 \mathrm{~h}$ at $823 \mathrm{~K}$ presented the peak at $853.1 \mathrm{eV}$ characteristics of $\mathrm{Ni}^{0}$ and also an additional peak at $857.8 \mathrm{eV}$ arising from the presence of $\mathrm{Ni}^{2+}$ species in Ni phyllosilicates. This latter result confirms that $\mathrm{Ni}$ is only partially reduced to $\mathrm{Ni}^{0}$ in $\mathrm{Ni} / \mathrm{SiO}_{2}-\mathrm{A}$ by $\mathrm{H}_{2}$ reduction at $823 \mathrm{~K}$, as it was inferred from the TPR experiments.

Table 1 shows that the Ni dispersions obtained by $\mathrm{H}_{2}$ chemisorption for reduced $\mathrm{Ni} / \mathrm{SiO}_{2}-\mathrm{I}$ and $\mathrm{Ni} / \mathrm{SiO}_{2}-\mathrm{Al}_{2} \mathrm{O}_{3}-\mathrm{I}$ were $3 \%$ and $5 \%$, respectively. These low $D_{\mathrm{NI}}$ values are consistent with the presence of large $\mathrm{NiO}$ particles in the calcined samples detected by XRD technique (Fig. 2). In contrast, the metal dispersion of $\mathrm{Ni} / \mathrm{SiO}_{2}-\mathrm{A}\left(D_{\mathrm{NI}}=25 \%\right)$ was markedly higher as compared to those of Ni samples prepared by wet impregnation. Such a difference in Ni particle sizes probably reflects the stronger metal-support interaction in Ni-containing phyllosilicates that also decreases the Ni reducibility.

The acid properties of $\mathrm{SiO}_{2}, \mathrm{SiO}_{2}-\mathrm{Al}_{2} \mathrm{O}_{3}$ and $\mathrm{Ni}$-supported samples were probed by TPD of $\mathrm{NH}_{3}$. The TPD curves are shown in Fig. 5 while the $\mathrm{NH}_{3}$ surface densities for acid sites obtained by deconvolution and integration of TPD traces are

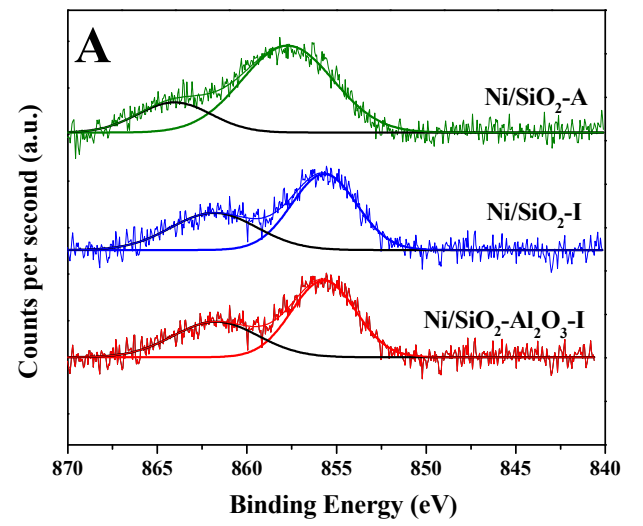

Table 2

$\mathrm{Ni} 2 p_{3 / 2}$ binding energies (BE) for calcined and reduced samples.

\begin{tabular}{lccccc}
\hline Catalyst & Treatment & $\begin{array}{c}\mathrm{Ni}^{2+} \\
(\mathrm{eV})\end{array}$ & $\begin{array}{c}\Delta E_{\mathrm{sat}}^{\mathrm{Ni}^{2+}} \\
(\mathrm{eV})\end{array}$ & $\begin{array}{c}\mathrm{Ni}^{0} \\
(\mathrm{eV})\end{array}$ & $\begin{array}{c}\Delta E_{\mathrm{sat}}^{\mathrm{Ni}^{0}} \\
(\mathrm{eV})\end{array}$ \\
\hline $\mathrm{Ni} / \mathrm{SiO}_{2}-\mathrm{I}$ & Calcined $^{\mathrm{b}}$ & 855.7 & 6.1 & - & - \\
& Reduced c $^{\mathrm{a}}$ & - & - & 853.0 & 3.5 \\
$\mathrm{Ni} / \mathrm{SiO}_{2}-\mathrm{Al}_{2} \mathrm{O}_{3}-\mathrm{I}$ & Calcined b $^{\mathrm{b}}$ & 855.7 & 6.0 & - & - \\
& Reduced d & - & - & 853.0 & 3.5 \\
$\mathrm{Ni} / \mathrm{SiO}_{2}-\mathrm{A}$ & Calcined b & 857.7 & 6.4 & - & - \\
& Reduced e & 857.8 & 6.3 & 853.1 & 3.5 \\
\hline
\end{tabular}

a Separation of $\mathrm{Ni} 2 p_{3 / 2}$ primary line to satellite.

b $2 \mathrm{~h}$ in air at $673 \mathrm{~K}$

c $1 \mathrm{~h}$ in $\mathrm{H}_{2}$ at $673 \mathrm{~K}$

d $1 \mathrm{~h}$ in $\mathrm{H}_{2}$ at $773 \mathrm{~K}$

e $1 \mathrm{~h}$ in $\mathrm{H}_{2}$ at $823 \mathrm{~K}$.

presented in Table 3. The $\mathrm{NH}_{3}$ evolved from $\mathrm{SiO}_{2}$ was negligible. The TPD curve of $\mathrm{SiO}_{2}-\mathrm{Al}_{2} \mathrm{O}_{3}$ showed an asymmetric broad band between 470 and $1100 \mathrm{~K}$ with a maximum at about $575 \mathrm{~K}$ (Fig. 5(A)). Calcined $\mathrm{Ni} / \mathrm{SiO}_{2}$-I presented two small $\mathrm{NH}_{3}$ desorption peaks at 573 and $773 \mathrm{~K}$ (Fig. 5(B)), which reflect the presence of $\mathrm{NiO}$ on the catalyst surface. After reduction, $\mathrm{Ni} / \mathrm{SiO}_{2}$-I sample did not show any $\mathrm{NH}_{3}$ desorption peak, thereby indicating the absence of surface acid sites (Fig. 5(C)).

Calcined $\mathrm{Ni} / \mathrm{SiO}_{2}-\mathrm{Al}_{2} \mathrm{O}_{3}-\mathrm{I}$ exhibited an asymmetric $\mathrm{NH}_{3}$ desorption band with a maximum at around 545-580 K, qualitatively similar to that of $\mathrm{SiO}_{2}-\mathrm{Al}_{2} \mathrm{O}_{3}$ support (Fig. 5(B)) However, the acid site density was lower on calcined $\mathrm{Ni} / \mathrm{SiO}_{2}-\mathrm{Al}_{2} \mathrm{O}_{3}-\mathrm{I}(251$ $\mu \mathrm{mol} / \mathrm{g})$ than on $\mathrm{SiO}_{2}-\mathrm{Al}_{2} \mathrm{O}_{3}(320 \mu \mathrm{mol} / \mathrm{g})$, probably because of the covering of acid sites by $\mathrm{NiO}$ crystallites. On the other hand, the amount of $\mathrm{NH}_{3}$ evolved from the reduced $\mathrm{Ni} / \mathrm{SiO}_{2}-\mathrm{Al}_{2} \mathrm{O}_{3}-\mathrm{I}$ sample was less than that of the calcined one (Table 3) due to the reduction of acid $\mathrm{Ni}^{2+}$ species to metallic $\mathrm{Ni}$. The $\mathrm{NH}_{3}$-TPD of calcined $\mathrm{Ni} / \mathrm{SiO}_{2}-\mathrm{A}$ showed a broad desorption band between 473 and $1023 \mathrm{~K}$, centered at $723 \mathrm{~K}$ (Fig. 5(B)). This sample exhibited the highest density of surface acid sites (539 $\mu \mathrm{mol} / \mathrm{g}$ ), derived from the presence of $\mathrm{Ni}^{2+}$ species in phyllosilicate-type nickel compounds. After reduction in $\mathrm{H}_{2}$ at $823 \mathrm{~K}$ for $1 \mathrm{~h}$, the concentration of acid sites on $\mathrm{Ni} / \mathrm{SiO}_{2}-\mathrm{A}$ diminished to only $228 \mu \mathrm{mol} / \mathrm{g}$ indicating that much of the $\mathrm{Ni}^{2+}$ ions were not reduced by the $\mathrm{H}_{2}$ treatment, which is in agreement with the results obtained by TPR and XPS.

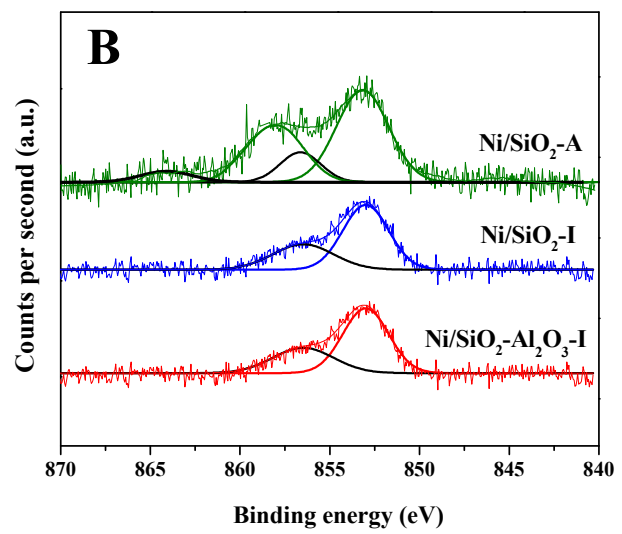

Fig. 4. XPS spectra of different samples. (A) calcined samples; (B) reduced samples. 

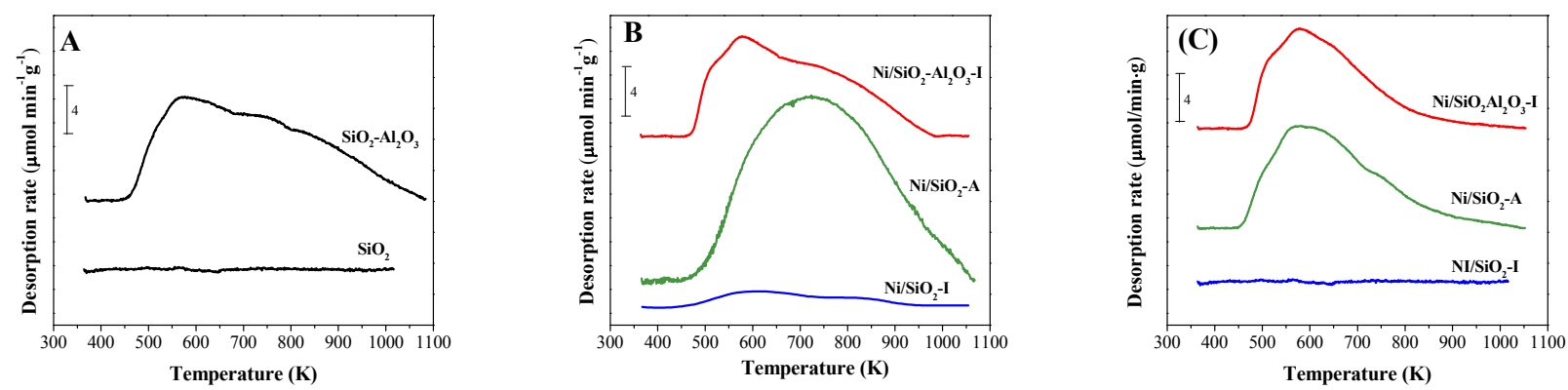

Fig. 5. TPD profiles of $\mathrm{NH}_{3}$ for: (A) supports; (B) calcined samples; (C) reduced samples

Table 3

Characterization of sample acidity by TPD of $\mathrm{NH}_{3}$.

\begin{tabular}{llc}
\hline Sample & Treatment & $\begin{array}{c}\text { Density of acid sites } \\
(\mu \mathrm{mol} / \mathrm{g})\end{array}$ \\
\hline $\mathrm{SiO}_{2}$ & Calcined $^{\mathrm{a}}$ & 0 \\
$\mathrm{SiO}_{2}-\mathrm{Al}_{2} \mathrm{O}_{3}$ & Calcined $^{\mathrm{a}}$ & 320 \\
$\mathrm{Ni} / \mathrm{SiO}_{2}-\mathrm{I}$ & Calcined $^{\mathrm{a}}$ & 32 \\
& Reduced $^{\mathrm{b}}$ & 0 \\
$\mathrm{Ni} / \mathrm{SiO}_{2}-\mathrm{Al}_{2} \mathrm{O}_{3}-\mathrm{I}$ & Calcined $^{\mathrm{a}}$ & 251 \\
& Reduced $^{\mathrm{c}}$ & 191 \\
$\mathrm{Ni} / \mathrm{SiO}_{2}-\mathrm{A}$ & Calcined a $^{\mathrm{a}}$ & 539 \\
& Reduced $^{\mathrm{d}}$ & 228 \\
\hline
\end{tabular}

a $2 \mathrm{~h}$ in air at $673 \mathrm{~K}$

b $1 \mathrm{~h}$ in $\mathrm{H}_{2}$ at $673 \mathrm{~K}$

c $1 \mathrm{~h}$ in $\mathrm{H}_{2}$ at $773 \mathrm{~K}$

d $1 \mathrm{~h}$ in $\mathrm{H}_{2}$ at $823 \mathrm{~K}$

The nature and strength of surface acid sites for reduced $\mathrm{Ni} / \mathrm{SiO}_{2}-\mathrm{Al}_{2} \mathrm{O}_{3}-\mathrm{I}$ and $\mathrm{Ni} / \mathrm{SiO}_{2}-\mathrm{A}$ samples were investigated by analyzing the FTIR spectra obtained after adsorption of pyridine at RT and outgassing at 423, 573 and 723 K (Fig. 6). Pyridine adsorbed on Brønsted acid sites (B) shows absorption bands at 1540, 1480-1500 and $1640 \mathrm{~cm}^{-1}$ while coordinately bound pyridine on Lewis acid sites (L) produces characteristic bands at 1440-1460, 1480-1500 and $1600 \mathrm{~cm}^{-1}$ [43-45]. Here, we determined the relative contribution of Lewis and Brønsted acid sites by deconvolution and integration of pyridine absorption bands at around 1455 and $1545 \mathrm{~cm}^{-1}$, respectively. Results in Table 4 show that both catalysts contain mainly Lewis acid sites; the $\mathrm{L} / \mathrm{B}$ ratios for reduced $\mathrm{Ni} / \mathrm{SiO}_{2}-\mathrm{A}$ and $\mathrm{Ni} / \mathrm{SiO}_{2}-\mathrm{Al}_{2} \mathrm{O}_{3}-\mathrm{I}$ were, in fact, 2.9 and 2.6 after degassing at $423 \mathrm{~K}$, respectively.
Table 4

IR spectroscopy of adsorbed pyridine: Lewis (L) and Brønsted (B) peak areas as a function of degassing temperature.

\begin{tabular}{lccccc}
\hline Catalyst & $\begin{array}{c}\text { Outgassing } T \\
(\mathrm{~K})\end{array}$ & $\begin{array}{c}\mathrm{L} \\
(\text { Area/g) }\end{array}$ & $\begin{array}{c}\mathrm{B} \\
\text { (Area/g) }\end{array}$ & $\begin{array}{c}\mathrm{L}+\mathrm{B} \\
(\text { Area/g) }\end{array}$ & L/B \\
\hline $\mathrm{Ni} / \mathrm{SiO}_{2}-\mathrm{A}^{\mathrm{a}}$ & 423 & 201 & 68 & 269 & 2.9 \\
& 573 & 151 & 27 & 178 & 5.6 \\
& 723 & 50 & 14 & 64 & 3.6 \\
$\mathrm{Ni} / \mathrm{SiO}_{2}-\mathrm{Al}_{2} \mathrm{O}_{3}-\mathrm{I}^{\mathrm{b}}$ & 423 & 151 & 57 & 208 & 2.6 \\
& 573 & 89 & 21 & 110 & 4.2 \\
& 723 & 26 & 5 & 31 & 5.2 \\
\hline
\end{tabular}

a Reduced $1 \mathrm{~h}$ in $\mathrm{H}_{2}$ at $823 \mathrm{~K}$

b Reduced $1 \mathrm{~h}$ in $\mathrm{H}_{2}$ at $773 \mathrm{~K}$

Moreover, the L/B ratio increased with degassing temperature, thereby revealing that both samples possess strong Lewis acidity. The total density of $(\mathrm{L}+\mathrm{B})$ acid sites determined for $\mathrm{Ni} / \mathrm{SiO}_{2}-\mathrm{A}$ was about $30 \%$ higher than for $\mathrm{Ni} / \mathrm{SiO}_{2}-\mathrm{Al}_{2} \mathrm{O}_{3}-\mathrm{I}$ after degassing at $423 \mathrm{~K}$, and two times higher after degassing at 723 K (Table 4). Besides, Fig. 7 shows the FTIR spectra in the hydroxyl stretching region of reduced $\mathrm{Ni} / \mathrm{SiO}_{2}-\mathrm{Al}_{2} \mathrm{O}_{3}-\mathrm{I}$ and $\mathrm{Ni} / \mathrm{SiO}_{2}-\mathrm{A}$ samples obtained after degassing at $723 \mathrm{~K}$ for $4 \mathrm{~h}$, and after pyridine adsorption at room temperature and degassing at $423 \mathrm{~K}$ for $0.5 \mathrm{~h}$. Difference spectra are also included. The position of the IR band for the $\mathrm{O}-\mathrm{H}$ stretching modes over degassed samples was about $3742-3745 \mathrm{~cm}^{-1}$. The difference spectra in Fig. 7 give insight on Brønsted acid site strength. It is observed that after desorption at $423 \mathrm{~K}$ of the pyridine adsorbed at room temperature, the base is almost completely eliminated on $\mathrm{Ni} / \mathrm{SiO}_{2}-\mathrm{Al}_{2} \mathrm{O}_{3}-\mathrm{I}$ but remains adsorbed to a signif-
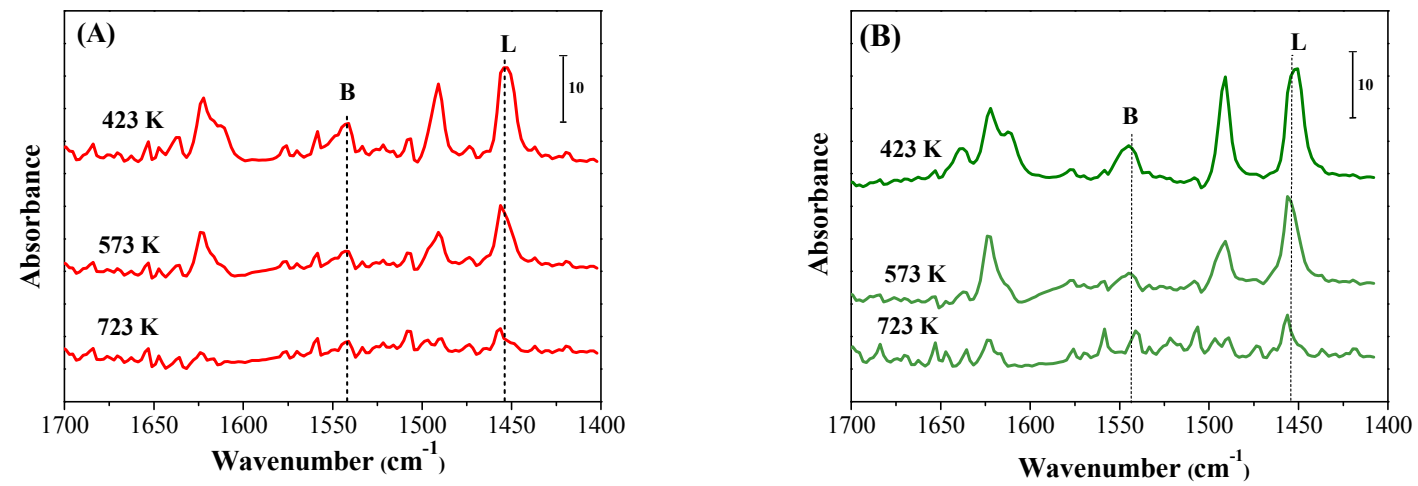

Fig. 6. FT-IR spectra of obtained after pyridine adsorption and outgassing at $423 \mathrm{~K}, 573 \mathrm{~K}$ and $723 \mathrm{~K}$ over reduced $\mathrm{Ni} / \mathrm{SiO}_{2}-\mathrm{Al}_{2} \mathrm{O}_{3}-\mathrm{I}(\mathrm{A})$ and $\mathrm{Ni} / \mathrm{SiO}_{2}-\mathrm{A}$ (B). 


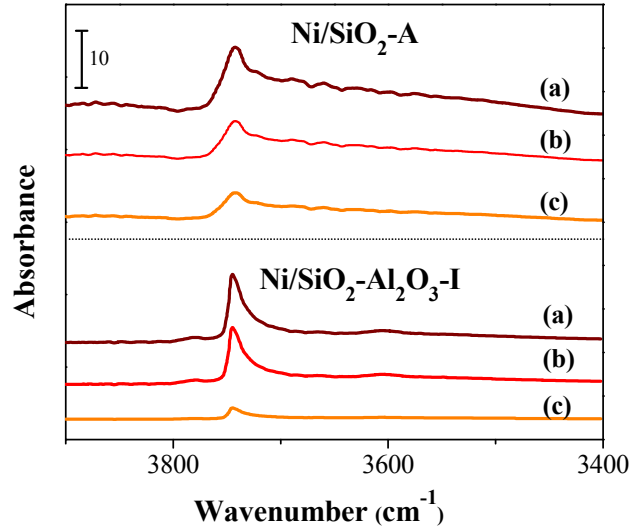

Fig. 7. IR in the hydroxyl region. (a) After degassing at $723 \mathrm{~K}$ for $4 \mathrm{~h}$; (b) after pyridine adsorption and degassing at $423 \mathrm{~K}$ for $0.5 \mathrm{~h}$; (c) difference spectra.

icant extent on $\mathrm{Ni} / \mathrm{SiO}_{2}-\mathrm{A}$. This result reflects the stronger acidity of surface $\mathrm{OH}$ groups on $\mathrm{Ni} / \mathrm{SiO}_{2}-\mathrm{A}$ compared to $\mathrm{Ni} / \mathrm{SiO}_{2}-\mathrm{Al}_{2} \mathrm{O}_{3}$-I, probably formed from the $\mathrm{Ni}$ phyllosilicates phase. No absorption bands were detected in the $\mathrm{O}-\mathrm{H}$ stretching region on $\mathrm{Ni} / \mathrm{SiO}_{2}-\mathrm{I}$, indicating that the hydroxyl group concentration on the surface was negligible. All these results obtained by FTIR of adsorbed pyridine reveal that $\mathrm{Ni} / \mathrm{SiO}_{2}-\mathrm{A}$ reduced $1 \mathrm{~h}$ in $\mathrm{H}_{2}$ at $823 \mathrm{~K}$ contains more and stronger acid sites than $\mathrm{Ni} / \mathrm{SiO}_{2}-\mathrm{Al}_{2} \mathrm{O}_{3}-\mathrm{I}$ reduced $1 \mathrm{~h}$ at $773 \mathrm{~K}$.

In brief, the results of catalyst characterization show that $\mathrm{Ni} / \mathrm{SiO}_{2}-\mathrm{I}$ and $\mathrm{Ni} / \mathrm{SiO}_{2}-\mathrm{A}$ present different physicochemical properties. Calcined $\mathrm{Ni} / \mathrm{SiO}_{2}$-I contains large $\mathrm{NiO}$ particles of low interaction with the support, that are completely reduced to large $\mathrm{Ni}^{0}$ crystallites following treatment in $\mathrm{H}_{2}$ at $673 \mathrm{~K}$; reduced $\mathrm{Ni} / \mathrm{SiO}_{2}$-I is a non-acidic catalyst. In contrast, calcined $\mathrm{Ni} / \mathrm{SiO}_{2}-\mathrm{A}$ contains small $\mathrm{NiO}$ particles along with $\mathrm{Ni}^{2+}$ species strongly interacting with the support. Treatment of $\mathrm{Ni} / \mathrm{SiO}_{2}-\mathrm{A}$ in $\mathrm{H}_{2}$ at $823 \mathrm{~K}$ reduces only about $55 \%$ of nickel to metallic $\mathrm{Ni}$. Reduced $\mathrm{Ni} / \mathrm{SiO}_{2}-\mathrm{A}$ is an acidic catalyst containing mainly Lewis sites due to the presence of $\mathrm{Ni}^{2+}$ species in $\mathrm{Ni}$ phyllosilicates of low reducibility.

\section{2. $\quad$ Catalytic tests}

Fig. 8 shows the evolution of $\mathrm{BN}$ conversion $\left(X_{\mathrm{BN}}\right)$ and yields $\left(Y_{\mathrm{i}}\right)$ as a function of time for the three catalysts used in this work. Quantitative data obtained from catalytic tests are given in Table 5. Specifically, Table 5 presents the initial BN conversion rates per gram of metal $\left(r_{\mathrm{BN}}^{0}, \mathrm{mmol} /\left(\mathrm{h}_{\mathrm{Ni}}\right)\right)$, the initial turnover frequencies (TOF, $\mathrm{min}^{-1}$ ), and the values of $X_{\mathrm{BN}}$ and selectivities $\left(S_{\mathrm{i}}\right)$ obtained at the end of the runs. The $r_{\mathrm{BN}}^{0}$ values were determined from the experimental curves of Fig. 8 by polynomial regression and numerical differentiation at $t=0$. In all the cases, the carbon balance was approximately $100 \%$.

Regarding the catalyst activity, data in Table 5 show that $r_{\mathrm{BN}}^{0}$ and TOF followed the trend $\mathrm{Ni} / \mathrm{SiO}_{2}-\mathrm{Al}_{2} \mathrm{O}_{3}-\mathrm{I}>\mathrm{Ni} / \mathrm{SiO}_{2}-\mathrm{A}>$ $\mathrm{Ni} / \mathrm{SiO}_{2}-\mathrm{I}$, although the values were of the same order and $\mathrm{BN}$ was completely converted at the end of the runs on the three catalysts. The higher activity observed on $\mathrm{Ni} / \mathrm{SiO}_{2}-\mathrm{A}$ as compared to $\mathrm{Ni} / \mathrm{SiO}_{2}$-I probably reflects the presence of a high density of acid sites on $\mathrm{Ni} / \mathrm{SiO}_{2}-\mathrm{A}$ (Table 3 ) whereas $\mathrm{Ni} / \mathrm{SiO}_{2}-\mathrm{I}$ is a non-acidic catalyst. In contrast, the product distribution was markedly different when comparing the results obtained with $\mathrm{Ni} / \mathrm{SiO}_{2}-\mathrm{I}$ and $\mathrm{Ni} / \mathrm{SiO}_{2}-\mathrm{A}$ catalysts. $\mathrm{Ni} / \mathrm{SiO}_{2}-\mathrm{I}$ formed initially $\mathrm{BA}$ and BBA. The BA yield increased with the progress of the reaction reaching $80 \%$ at the end of the run (Fig. 8). The local slopes of the $Y_{\mathrm{i}}$ curves in Fig. 8 give the formation rate of product $i$ at a specific BN conversion and reaction time. The DBA formation curve on $\mathrm{Ni} / \mathrm{SiO}_{2}$-I presented a zero initial slope indicating that DBA is a secondary product, which agrees with the reaction pathways depicted in Fig. 1 for BN hydrogenation. At the end of the run, DBA was the only byproduct of the reaction $\left(Y_{\mathrm{DBA}}=\right.$ $18 \%)$. BBA was formed at the beginning of the reaction and then went through a maximum because it was progressively hydrogenated to DBA.

$\mathrm{Ni} / \mathrm{SiO}_{2}-\mathrm{A}$ formed selectively a mixture of DBA and TBA
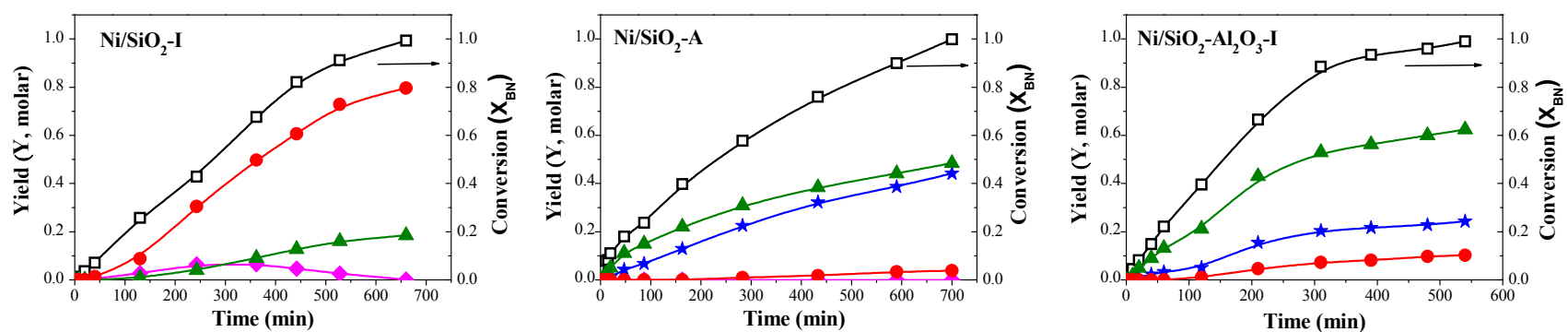

Fig. 8. Catalytic results: butyronitrile conversion $\left(\mathrm{XB}_{\mathrm{N}}\right)$ and yields (Yi). $\bullet$ Butylamine (BA), $\Delta$ Dibutylamine (DBA), $\diamond$ Butylidene-butylamine (BBA), $\star$ Tributylamine (TBA). [T= $373 \mathrm{~K}, P=13 \mathrm{bar}$, Solvent: ethanol, $W$ cat $=1 \mathrm{~g}]$

Table 5

Catalytic results for butyronitrile hydrogenation.

\begin{tabular}{|c|c|c|c|c|c|c|c|}
\hline \multirow{2}{*}{ Catalyst } & \multicolumn{2}{|c|}{ Initial activity } & \multicolumn{5}{|c|}{ BN conversion $\left(X_{\mathrm{BN}}\right)$ and selectivities $\left(S_{\mathrm{i}}\right)$ at the end of reaction } \\
\hline & $r_{\mathrm{BN}}^{0}\left(\mathrm{mmol} / \mathrm{h} \mathrm{g}_{\mathrm{Ni}}\right)$ & TOF $\left(\min ^{-1}\right)$ & $X_{\mathrm{BN}}(\%)$ & $S_{\mathrm{BA}}(\%)$ & $S_{\mathrm{DBA}}(\%)$ & $S_{\text {ТВA }}(\%)$ & $S_{\text {Others }}(\%)$ \\
\hline $\mathrm{Ni} / \mathrm{SiO}_{2}-\mathrm{I}$ & 126 & 4.1 & 100 & 80 & 18 & - & 2 \\
\hline $\mathrm{Ni} / \mathrm{SiO}_{2}-\mathrm{A}$ & 334 & 5.2 & 100 & 4 & 49 & 45 & 2 \\
\hline $\mathrm{Ni} / \mathrm{SiO}_{2}-\mathrm{Al}_{2} \mathrm{O}_{3}-\mathrm{I}$ & 351 & 6.7 & 100 & 10 & 63 & 25 & 2 \\
\hline
\end{tabular}

Reaction conditions: $T=373 \mathrm{~K}, P=13$ bar $\left(\mathrm{H}_{2}\right), 800 \mathrm{rpm}$, solvent: Ethanol $(150 \mathrm{ml}), W_{\mathrm{cat}}=1 \mathrm{~g}, V_{\mathrm{BN}}=3 \mathrm{ml}$. 
from the beginning of the reaction (Fig. 8). At the end of reaction, for $X_{\mathrm{BN}}=100 \%$, the selectivities to DBA $y$ TBA were $49 \%$ and $45 \%$ respectively. In contrast with the results obtained on $\mathrm{Ni} / \mathrm{SiO}_{2}-\mathrm{I}, \mathrm{BBA}$ was not detected during the entire catalytic run whereas BA was observed in negligible amounts only at the end of the run.

$\mathrm{Ni} / \mathrm{SiO}_{2}-\mathrm{Al}_{2} \mathrm{O}_{3}-\mathrm{I}$ formed preferentially DBA during the entire catalytic test together with minor amounts of TBA and BA (Fig. 8). At the end of the run, the DBA yield was $63 \%$ while $Y_{\text {TВA }}$ and $Y_{\mathrm{BA}}$ were $25 \%$ and $10 \%$, respectively (Table 5).

\subsection{Catalyst reuse}

The possibility of reusing $\mathrm{Ni} / \mathrm{SiO}_{2}-\mathrm{I}$ and $\mathrm{Ni} / \mathrm{SiO}_{2}-\mathrm{A}$ for butyronitrile hydrogenation was evaluated by performing three consecutive catalytic tests and regenerating the catalyst at the end of the runs. The following catalyst regeneration procedure was employed: (1) the catalyst was recovered by filtration at the end of the run, dried at $373 \mathrm{~K}$ for $12 \mathrm{~h}$ and calcined in air ( $60 \mathrm{ml} / \mathrm{min}$ ) for $2 \mathrm{~h}$ at $773 \mathrm{~K}$; (2) then the catalyst was reduced ex-situ in $\mathrm{H}_{2}\left(1 \mathrm{~h}\right.$ at 673 and $823 \mathrm{~K}$ for Ni/SiO $2-\mathrm{I}$ and $\mathrm{Ni} / \mathrm{SiO}_{2}-\mathrm{A}$, respectively) and loaded under inert atmosphere to the reactor to perform the catalytic run under standard conditions (373 K, 13 bar). Results in Fig. 9 show that the $X_{\mathrm{BN}}$ vs $t$ and $Y_{\mathrm{i}}$ vs $t$ curves were similar in the three consecutive catalytic runs for $\mathrm{Ni} / \mathrm{SiO}_{2}-\mathrm{I}$ and $\mathrm{Ni} / \mathrm{SiO}_{2}-\mathrm{A}$, thereby showing that both catalysts may be successfully regenerated and reused after reaction.

\section{Discussion}

The catalytic results of Fig. 8 and Table 5 clearly show that the preparation method may drastically change the activity and selectivity of $\mathrm{Ni} / \mathrm{SO}_{2}$ catalysts for the hydrogenation of nitriles. $\mathrm{Ni} / \mathrm{SiO}_{2}$-I, obtained by incipient wetness impregnation, was a non-acidic catalyst containing large $\mathrm{Ni}^{0}$ particles of low interaction with the support. $\mathrm{Ni} / \mathrm{SiO}_{2}$-I formed essentially $\mathrm{BA}$, which is in agreement with previous reports showing that Raney-Ni and Ni-supported catalysts prepared by wet impregnation yield selectively the primary amine when BN hydrogenation is conducted in alcohols such as ethanol $[6,8,10,46]$. The selective formation of BA from BN on Ni catalysts has been explained by considering that $\mathrm{BN}$ is adsorbed on $\mathrm{Ni}$ via nitrene intermediates $[47,48]$. The strong binding of BN with Ni through the nitrogen atom would promote fast hydrogenation of the carbon atom in the nitrile group, which prevents secondary condensation reactions. $\mathrm{Ni} / \mathrm{SiO}_{2}-\mathrm{A}$, obtained by the ammonia method, was an acid catalyst containing small $\mathrm{Ni}^{0}$ particles in close interaction with Ni phyllosilicates of low reducibility. In contrast with the product distribution observed on $\mathrm{Ni} / \mathrm{SiO}_{2}-\mathrm{I}, \mathrm{Ni} / \mathrm{SiO}_{2}-\mathrm{A}$ formed from BN essentially DAB and TBA and only negligible amounts of BA.

Our characterization data show that the main difference between reduced $\mathrm{Ni} / \mathrm{SiO}_{2}-\mathrm{A}$ and $\mathrm{Ni} / \mathrm{SiO}_{2}-\mathrm{I}$ catalysts is that the former contains a high density of surface acid sites $(228 \mu \mathrm{mol}$ $\mathrm{NH}_{3} / \mathrm{g}$ ) while the latter is a non-acidic catalyst. In this regard, is significant noting that very few papers have investigated the effect of the acid properties of support on the Ni selectivity for nitrile hydrogenation reactions. Volf et al. [49] in a review paper on nitrile hydrogenation concluded that the catalyst selectivity is essentially determined by the metal nature and the reaction conditions, while the support has a minor influence on the reaction. Huang et al. [17] studied the acetonitrile and butyronitrile hydrogenations on Ru-supported catalysts and reported that the acidity of the support has no significant effect on selectivity. In contrast, Verhaak et al. [15] stated that in the hydrogenation of acetonitrile on Ni supported on different solids, the formation of condensation products, diethyl- and triethylamine, increases with the support acidity. Similarly, Hao et al. [16] observed that in the butyronitrile hydrogenation on Pd-supported catalysts the acidity of support favors the condensation steps.

Regarding the effect of the metal nature on nitrile hydrogenation selectivity, it is generally accepted that that the selec-
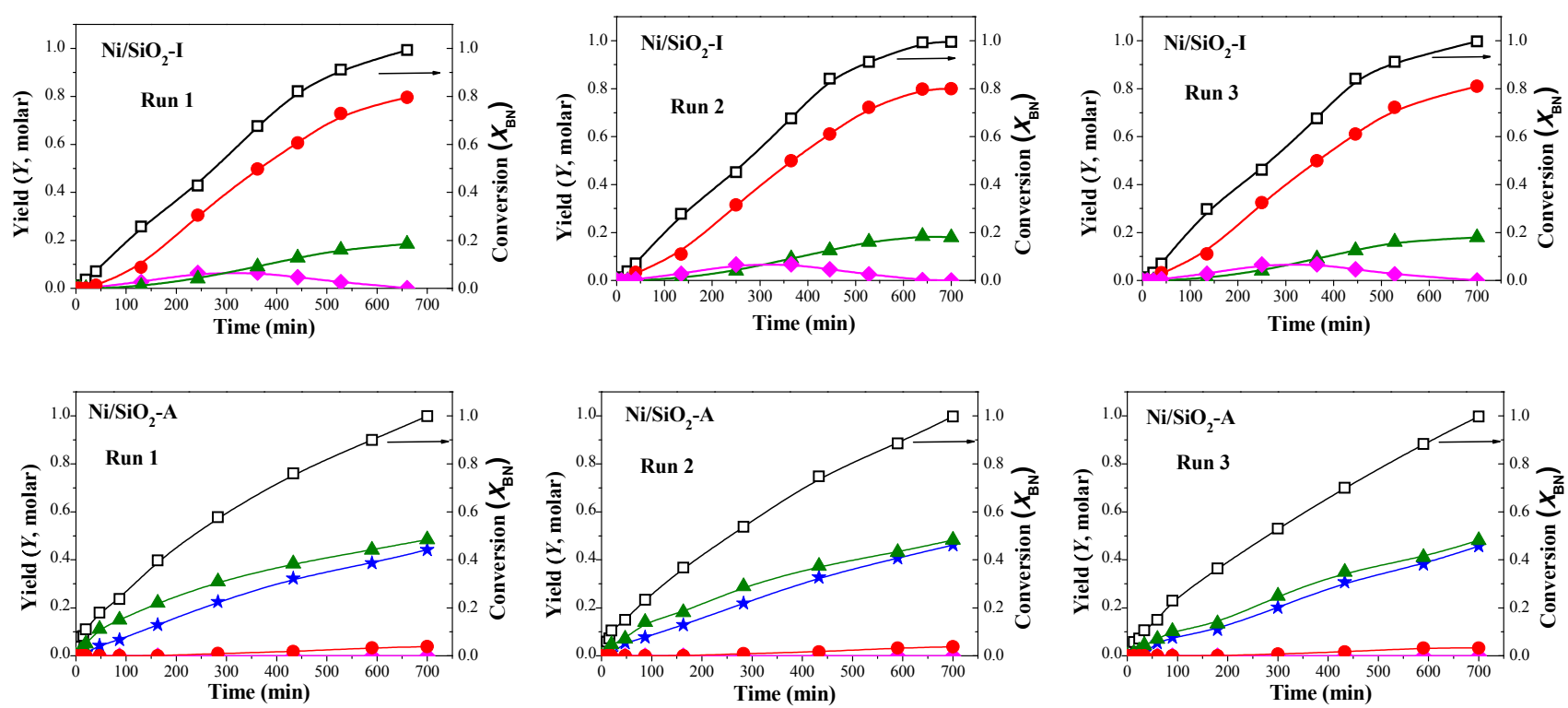

Fig. 9. Reuse of $\mathrm{Ni} / \mathrm{SiO}_{2}-\mathrm{I}$ and $\mathrm{Ni} / \mathrm{SiO}_{2}-\mathrm{A}$ in three consecutive catalytic tests. $\bullet \mathrm{BA}, \Delta \mathrm{DBA}, \star \mathrm{TBA}$. $[T=373 \mathrm{~K}, P=13 \mathrm{bar}$, Solvent: ethanol, $W$ cat $=1 \mathrm{~g}$ ]. 
tive formation of primary amines takes place via nitrile intermediates, while the formation of secondary and tertiary amines occurs via carbene or aldimine intermediates [8,50-52]. According to the reaction network in Fig. 1, the formation of DBA requires the readsorption of $\mathrm{BA}$ on the catalyst surface to react with butylimine and produce the secondary amine. Similarly, DBA readsorption is required to form the tertiary amine. The DBA formation mechanism involves the nucleophilic addition of BA via the lone electron pair on the nitrogen atom at the unsaturated carbon atom in the aldimine (or carbene) intermediate, forming 1-amino-dialkylamine that by deamination and final hydrogenation transforms to DBA. In a previous work [12], we found that on Pd and Pt the formation of BA from BN is almost completely suppressed, and both metals produce preferentially DBA and TBA, which is qualitatively similar to the results obtained here on $\mathrm{Ni} / \mathrm{SiO}_{2}-\mathrm{A}$. We explained the results obtained on Pt and Pd by considering that the butylimine/BA condensation leading to DBA (Fig. 1) occurs between adsorbed species, i.e. without desorption of BA to the liquid phase. This proposal was supported by BN TPD experiments showing that $\mathrm{BN}$-derived intermediates are strongly adsorbed on both metals [12]. A similar explanation may account here for the selective formation of DBA and $\mathrm{TBA}$ on $\mathrm{Ni} / \mathrm{SiO}_{2}-\mathrm{A}$ by considering that $\mathrm{BA}$ is not release to the liquid phase because it is strongly adsorbed on surface acid sites contiguous to $\mathrm{Ni}^{0}$ atoms. In order the verify this assumption, we investigate the strength of BA-catalyst interactions by performing additional BA TPD experiments on reduced $\mathrm{Ni} / \mathrm{SiO}_{2}-\mathrm{I}, \mathrm{Ni} / \mathrm{SiO}_{2}-\mathrm{A}$ and $\mathrm{Ni} / \mathrm{SiO}_{2}-\mathrm{Al}_{2} \mathrm{O}_{3}-\mathrm{I}$. The obtained TPD curves are presented in Fig. 10. On the three catalysts, the signals of $m / z=2,28$ and 30 corresponding to fragments of $\mathrm{H}_{2}, \mathrm{C} 2$ and $\mathrm{BA}$, respectively, were followed by mass spectrometry. The desorption of $\mathrm{BA}$ on $\mathrm{Ni} / \mathrm{SiO}_{2}-\mathrm{I}$ (Fig. $10(A)$ ) occurred as a small peak at $406 \mathrm{~K}$, suggesting that a substantial amount of BA was eliminated from the catalyst by the pretreatment with He at RT. Besides, no signals of evolved compounds accounting for possible decomposition of BA molecule were detected thereby revealing a weak interaction between $\mathrm{BA}$ and $\mathrm{Ni} / \mathrm{SiO}_{2}-\mathrm{I}$. The TPD of $\mathrm{BA}$ on $\mathrm{Ni} / \mathrm{SiO}_{2}-\mathrm{A}$ (Fig. 10(B)) shows a large peak corresponding to the most abundant BA ion ( $m / z=30$ signal) with a maximum at $437 \mathrm{~K}$, i.e. shifted about $30 \mathrm{~K}$ to higher temperatures as compared to BA evolution on $\mathrm{Ni} / \mathrm{SiO}_{2}$-I. Two additional broad bands corresponding to high temperature $\mathrm{H}_{2}$ evolution $(\mathrm{m} / \mathrm{z}=2)$ were detected at 573 and $851 \mathrm{~K}$ respectively, which were accompanied by the $\mathrm{C} 2$ fragment evolution $(m / z=28)$. These evolutions indicate the presence of surface sites on which BA adsorbs very strongly and decomposes at high temperatures. The BA TPD curve on $\mathrm{Ni} / \mathrm{SiO}_{2}-\mathrm{Al}_{2} \mathrm{O}_{3}$-I (Fig. $10(\mathrm{C})$ ) presents the $m / z=30$ peak at 425 $\mathrm{K}$ while the evolutions of $\mathrm{H}_{2}$ and the $\mathrm{C} 2$ fragment $(\mathrm{m} / \mathrm{z}=28)$ gave rise to two broad bands at about 520 and $748 \mathrm{~K}$. Qualitatively, the evolutions of $m / z=2,28,30$ signals on $\mathrm{Ni} / \mathrm{SiO}_{2}-\mathrm{A}$ and $\mathrm{Ni} / \mathrm{SiO}_{2}-\mathrm{Al}_{2} \mathrm{O}_{3}-\mathrm{I}$ were similar, but the peak maxima appeared at lower temperatures on $\mathrm{Ni} / \mathrm{SiO}_{2}-\mathrm{Al}_{2} \mathrm{O}_{3}$-I thereby revealing that $\mathrm{BA}$ adsorption was stronger on $\mathrm{Ni} / \mathrm{SiO}_{2}-\mathrm{A}$. In summary, the BA TPD profiles in Fig. 10 show that the BA-catalyst interaction strength follows the trend $\mathrm{Ni} / \mathrm{SiO}_{2}-\mathrm{A}>$ $\mathrm{Ni} / \mathrm{SiO}_{2}-\mathrm{Al}_{2} \mathrm{O}_{3}-\mathrm{I}>\mathrm{Ni} / \mathrm{SiO}_{2}-\mathrm{I}$. The weaker adsorption of $\mathrm{BA}, \mathrm{a}$ basic molecule, on $\mathrm{Ni} / \mathrm{SiO}_{2}$-I reflects the absence of acid sites at the catalyst surface.

Results from Fig. 10 support the interpretation that the preferential formation of DBA nd TBA on $\mathrm{Ni} / \mathrm{SiO}_{2}-\mathrm{A}$ is due to the strong adsorption of $\mathrm{BA}$ on phyllosilicate acid sites in the vicinity of metallic Ni nanoparticles. BA is not release to the liquid phase and reacts on the catalyst surface with adsorbed imine intermediates to form secondary and tertiary amines, probably on the interphase of surface acid sites- $\mathrm{Ni}^{0}$ nanoparticles. Our results show, in fact, that reduction of calcined $\mathrm{Ni} / \mathrm{SiO}_{2}-\mathrm{A}$ with $\mathrm{H}_{2}$ at $823 \mathrm{~K}$ partially destroys Ni phyllosilicates and forms highly dispersed $\mathrm{Ni}^{0}$ nanoparticles in close contact with remaining unreduced phyllosilicates. Consistently, Sivaiah et al. [37] reported that the $\mathrm{Ni}$ phyllosilicates of formula $\mathrm{Ni}_{3} \mathrm{Si}_{2} \mathrm{O}_{5}(\mathrm{OH})_{4}$ (Ni 1:1 PS), consisting of a layer containing one tetrahedral sheet ( $\mathrm{Si}$ coordinated to four oxygen atoms) and one octahedral sheet $\left(\mathrm{Ni}^{2+}\right.$ cations coordinated to six oxygen atoms or hydroxyl groups), are partially destroyed by $\mathrm{H}_{2}$ reduction at temperatures higher than $773 \mathrm{~K}$. Characterization of reduced $\mathrm{Ni} / \mathrm{SiO}_{2}-\mathrm{A}$ by IR of adsorbed pyridine revealed that it contains Lewis and Brønsted acid sites in a $\mathrm{L} / \mathrm{B}=3$ ratio. Probably, the Lewis acid sites are coordinatively unsaturated $\mathrm{Ni}^{2+}$ sites near the edges/surfaces of phyllosilicate, as it has been proposed in previous work [53,54]. Fig. 11 illustrates the formation of dual Lewis acid- $\mathrm{Ni}^{0}$ sites on $\mathrm{Ni} / \mathrm{SiO}_{2}-\mathrm{A}$ upon reduction with $\mathrm{H}_{2}$ at $823 \mathrm{~K}$ of $\mathrm{Ni}^{2+}$ into $\mathrm{Ni}^{0}$ in the octahedral sheets of Ni 1:1 PS phyllosilicates. The resulting $\mathrm{Ni}^{0}$ nanoparticles would remain confined in the structure of unreduced $\mathrm{Ni}$ 1:2 PS phases that prevents the sintering of metallic Ni crystallites. Previous studies have reported, in fact, that reduction of Ni 1:2 PS phyllosilicates, consisting of layers of tetrahedral-octahedral-tetrahedral structure, does not take place for temperatures lower than about $973 \mathrm{~K}$ [37].
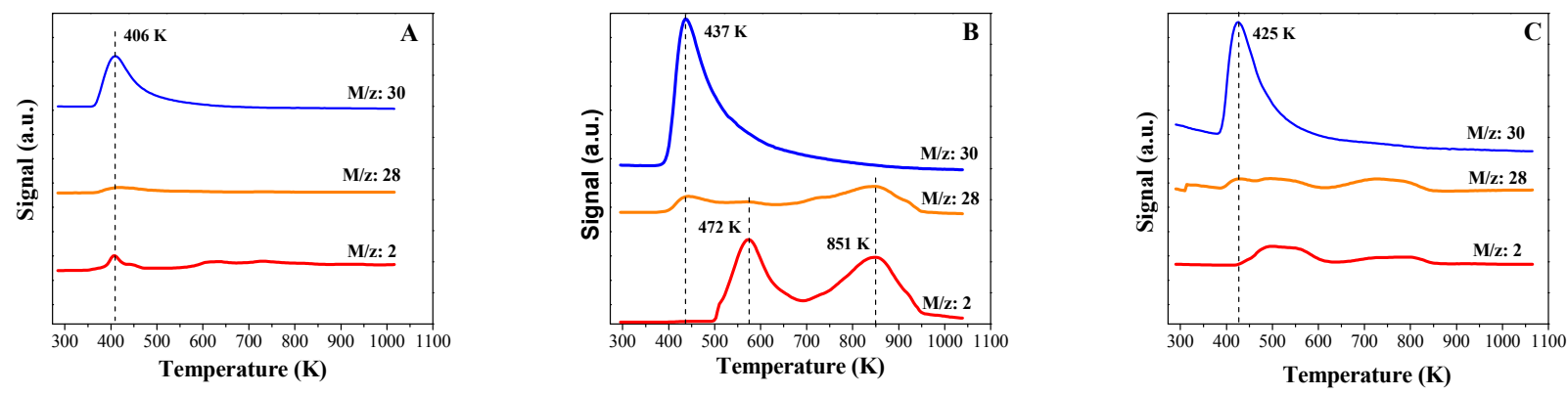

Fig. 10. TPD profiles of BA preadsorbed at $\mathrm{RT}$ on $\mathrm{Ni} / \mathrm{SiO}_{2}-\mathrm{I}(\mathrm{A}), \mathrm{Ni} / \mathrm{SiO}_{2}-\mathrm{A}(\mathrm{B})$ and $\mathrm{Ni} / \mathrm{SiO}_{2}-\mathrm{Al}_{2} \mathrm{O}_{3}-\mathrm{I}(\mathrm{C})$. [He stream: $60 \mathrm{~cm}^{3} / \mathrm{min}$ heating rate: 10 $\mathrm{K} / \mathrm{min}$ ]. 


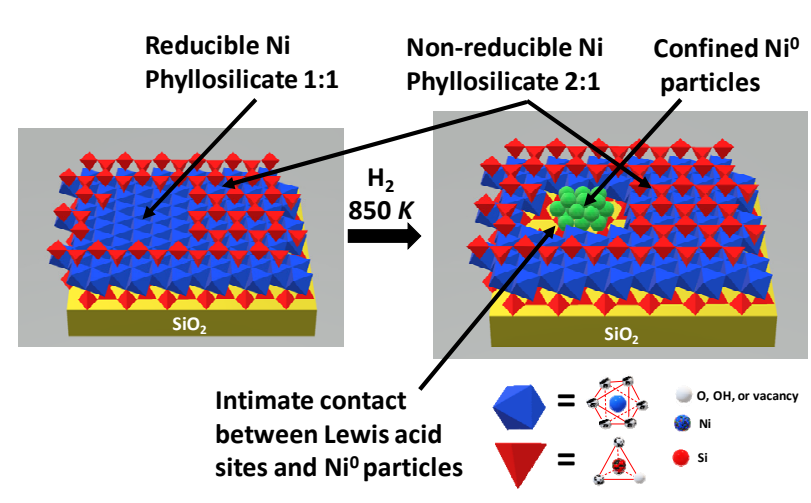

Fig. 11. Generation of dual Lewis acid- $\mathrm{Ni}^{0}$ sites on $\mathrm{Ni} / \mathrm{SiO}_{2}-\mathrm{A}$.

Like $\mathrm{Ni} / \mathrm{SiO}_{2}-\mathrm{A}, \mathrm{Ni} / \mathrm{SiO}_{2}-\mathrm{Al}_{2} \mathrm{O}_{3}-\mathrm{I}$ contains $\mathrm{Ni}^{0}$ and Lewis acid sites and produces mainly DBA and TBA with only minor amounts of BA. Nevertheless, the DBA/TBA ratio was lower on $\mathrm{Ni} / \mathrm{SiO}_{2}-\mathrm{A}(1.1)$ than on $\mathrm{Ni} / \mathrm{SiO}_{2}-\mathrm{Al}_{2} \mathrm{O}_{3}-\mathrm{I}$ (2.5). This is because $\mathrm{Ni} / \mathrm{SiO}_{2}-\mathrm{A}$ contains more and stronger acid sites than $\mathrm{Ni} / \mathrm{SiO}_{2}-\mathrm{Al}_{2} \mathrm{O}_{3}-\mathrm{I}$ and would promote better the surface reactions leading to TBA which involve the strong adsorption of BA and DBA intermediates.

\section{Conclusions}

The activity and selectivity of $\mathrm{Ni} / \mathrm{SiO}_{2}$ catalysts for the liquid-phase hydrogenation of butyronitrile to butylamine, dibutylamine and tributylamine depend significantly on the catalyst preparation method. $\mathrm{Ni} / \mathrm{SiO}_{2}$ catalysts obtained by incipient-wetness impregnation $\left(\mathrm{Ni} / \mathrm{SiO}_{2}-\mathrm{I}\right)$ do not contain acid sites and the active sites are metallic $\mathrm{Ni}$ atoms located at the surface of large $\mathrm{Ni}$ particles of low interaction with the support. $\mathrm{Ni} / \mathrm{SiO}_{2}$-I promotes the formation of butylamine, the primary amine; here, the butylamine selectivity on $\mathrm{Ni} / \mathrm{SiO}_{2}-\mathrm{I}$ was $80 \%$ at complete conversion of butyronitrile at $373 \mathrm{~K}$ and 13 bar. $\mathrm{Ni} / \mathrm{SiO}_{2}$ catalysts prepared by the ammonia method $\left(\mathrm{Ni} / \mathrm{SiO}_{2}-\mathrm{A}\right)$ present highly dispersed $\mathrm{Ni}^{0}$ nanoparticles in close contact with $\mathrm{Ni}$ phyllosilicates containing a high density of Lewis acid sites. $\mathrm{Ni} / \mathrm{SiO}_{2}-\mathrm{A}$ forms essentially similar amounts of dibutylamine and tributylamine, and only negligible amounts of butylamine. This is because butylamine is strongly adsorbed on phyllosilicate acid sites and reacts on the catalyst surface with adsorbed imine intermediates to form secondary and tertiary amines, probably on the interphase of surface acid sites- $\mathrm{Ni}^{0}$ nanoparticles. The results presented in this work show that selective formation of primary, secondary or tertiary amines from nitrile hydrogenation on $\mathrm{Ni} / \mathrm{SiO}_{2}$ may be tuned by selecting the proper catalyst preparation method.

\section{Acknowledgments}

Authors thank the Universidad Nacional del Litoral (UNL), Consejo Nacional de Investigaciones Científicas y Técnicas (CONICET), and Agencia Nacional de Promoción Científica y Tecnológica (ANPCyT), Argentina, for the financial support of this work.

\section{References}

[1] S. T. McMillan, P. K. Agrawal, Ind. Eng. Chem. Res., 1988, 27, 243-248.

[2] C. De Bellefon, P. Fouilloux, Catal. Rev. Sci. Eng., 1994, 36, 4, 59-506.

[3] P. Sabatier, J. B. Senderens, Compt. Rend. Acad. Sci., 1905, 140, 482-483.

[4] J. Von Braun, G. Blessing, F. Zobel, Ber. Dtsch. Chem. Ges., 1923, 36, 1988-2001.

[5] R. E. Juday, H. Adkins, J. Am. Chem. Soc., 1955, 77, 4559-4564.

[6] H. Greenfield, Ind. Eng. Chem. Prod. Res. Dev., 1967, 6, 142-144.

[7] P. Schärringer, T. E. Müller, J. A. Lercher, J. Catal., 2008, 253, 167-179.

[8] J. Krupka, J. Pasek, Curr. Org. Chem., 2012, 16, 988-1004.

[9] Y. Huang, W. M. H. Sachtler, Appl. Catal. A, 1999, 182, 365-378.

[10] D. J. Segobia, A. F. Trasarti, C. R. Apesteguia, Appl. Catal. A, 2012, 445, 69-78.

[11] J. Volf, J. Pasek, Stud. Surf. Sci. Catal., 1986, 27, 105-144.

[12] D. J. Segobia, A. F. Trasarti, C. R. Apesteguía, Catal. Sci. Technol,, 2014, 4, 4075-4083.

[13] D. J. Segobia, A. F. Trasarti, C. R. Apesteguía, Catal. Commu., 2015, 62, 62-66.

[14] D. J. Segobia, A. F. Trasarti, C. R. Apesteguía, J. Braz. Chem. Soc., 2014, 25, 2272-2279.

[15] M. J. F. M. Verhaak, A. J. van Dillen, J. W. Geus, Catal. Lett., 1994, 26, $37-53$.

[16] Y. Hao, X. Wang, N. Perret, F. Cardenas-Lizana, M. A. Keane, Catal. Struct. React., 2015, 1, 4-10

[17] Y. Huang, V. Adeeva, W. M. H. Sachtler, Appl. Catal. A, 2000, 196, 73-85.

[18] J. T. Richardson, R. J. Dubus, J. Catal., 1978, 54, 207-218.

[19] O. Clause, M. Kermarec, L. Bonneviot, F. Villain, M. Che, J. Am. Chem. Soc. 1992, 114, 4709-4717.

[20] M. Houalla, F. Delannay, I. Matsuura, B. Delmon, J. Chem. Soc., Faraday Trans 1, 1980, 76, 2128-2141.

[21] A. Barbier, A. Hanif, J. A. Dalmon, G. A. Martin, Appl. Catal. A, 1998, $168,333-343$.

[22] F. Le Normand, A. Borgna, T. F. Garetto, C. R. Apesteguia, B. Moraweck, J. Phys. Chem., 1996, 100, 9068-9076.

[23] J. S. Smith, P. A. Thrower, M. A. Vannice, J. Catal. 1981, 68, 270-285.

[24] P. Burattin, M. Che, C. Louis, J. Phys. Chem. B, 1997, 101, 7060-7074.

[25] M. V. Sivaiaha, S. Petit, J. Barrault, C. Batiot-Dupeyrat, S. Valange, Catal. Today, 2010, 157, 397-403.

[26] M. Che, Z. X. Cheng, C. J. Louis, Am. Chem. Soc., 1995, 117, 2008-2018

[27] M. G. da Fonseca, C. R. Silva, J. S. Barone, C. Airoldi, J. Mater. Chem., 2000, 10, 789-795.

[28] G. W. Brindley, D. L. Bish, H. M. Wan, Am. Mineral., 1979, 64, 615-625.

[29] C. Zhang, H. Yue, Z. Huang, S. Li, G. Wu, X. Ma, J. Gong, ACS Sustainable Chem. Eng., 2013, 1, 161-173

[30] B. Mile, D. Stirling, M. A. Zammitt, A. Lovell, M. Webb, J. Catal., 1998, 114, 217-229.

[31] K. Hadjiivanov, M. Mihaylov, D. Klissurski, P. Stefanov, N. Abadjieva, E. Vassileva, L. Mintchev, J. Catal., 1999, 185, 314-323.

[32] A. Lewandowska, S. Monteverdi, M. Bettahar, M. Ziolek, J. Mol. Catal. A, 2002, 188, 85-95.

[33] P. Castaño, B. Pawelec, J. L. G. Fierro, J. M. Arandes, J. Bilbao, Fuel, 2007, 86, 2262-2274. 


\section{Graphical Abstract}

Chin. J. Catal., 2019, 40: 1693-1703 doi: 10.1016/S1872-2067(18)63179-1

Effect of the catalyst preparation method on the performance of Ni-supported catalysts for the synthesis of saturated amines from nitrile hydrogenation

D. J. Segobia, A. F. Trasarti, C. R. Apesteguía *

INCAPE, UNL-CONICET, CCT Conicet-Paraje El Pozo, Argentina

$\mathrm{Ni} / \mathrm{SiO}_{2}$ prepared by the ammonia method forms selectively secondary and tertiary amines from butyronitrile hydrogenation. The catalyst contains $\mathrm{Ni}^{0}$ nanoparticles in close contact with $\mathrm{Ni}^{+2}$ species in Ni phyllosilicates that favor the condensation reactions.

[34] A. F. Trasarti, A. J. Marchi, C. R. Apesteguía, Catal. Comm., 2013, 32, 62-66.

[35] J. van de Loosdrecht, A. M. van der Kraan, A. J. van Dillen, J. W. Geus, J. Catal., 1997, 170, 217-226.

[36] A. Loaiza-Gil, M. Villarroel, J. F. Balbuena, M. A. Lacruz, S. Gonzalez-Cortés, J. Mol. Catal. A, 2008, 281, 207-213.

[37] M. V. Sivaiah, S. Petit, M. F. Beaufort, D. Eyidi, J. Barrault, C. Batiot-Dupeyrat, S. Valange, Microporous Mesoporous Mater., 2011, 140, 69-80.

[38] J. C. Vedrine, G. Hollinger, T. M. Duc, J. Phys. Chem., 1978, 82, 1515-1520.

[39] Z. Li, L. Mo, Y. Kathiraser, S. Kawi, ACS Catal., 2014, 4, 1526-1536.

[40] T. Lehmann, T. Wolff, C. Hamel, P. Veit, B. Garke, A. Seidel-Morgenstern, Microporous Mesoporous Mater., 2012, 151, 113-125.

[41] M. Yang, P. Jin, Y. Fan, C. Huang, N. Zhang, W. Weng, M. Chen, H. Wan, Catal. Sci. Technol., 2015, 5, 5095-5099.

[42] C. Guimona, A. Auroux, E. Romero, A. Monzon, Appl. Catal. A, 2003, 251, 199-214.
[43] J. W. Ward, J. Catal., 1968, 10, 34-46.

[44] H. Knozinger, Adv. Catal., 1976, 25, 184-271.

[45] G. Busca, Catal. Today, 1998, 41, 191-206.

[46] A. Chojecki, M. Veprek-Heijman, T. E. Müller, P. Schärringer, S. Veprek, J. A. Lercher, J. Catal., 2007, 245, 237-248.

[47] J. Y. Huang, W. M. H. Sachtler, J. Catal. 1999, 184, 247-261.

[48] A. Chojecki, H. Jobic, A. Jentys, T. E. Müller, J. A. Lercher, Catal. Lett., 2004, 97, 155-162.

[49] J. Volf, J. Pasek, Stud. Surf. Sci. Catal., 1986, 27, 105-144.

[50] B. Coq, D. Tichit, S. Ribet, J. Catal., 2000, 189, 117-125.

[51] P. Scharringer, T. E. Muller, A. Jentys, J. A. Lercher, J. Catal., 2009, $263,34-41$.

[52] C. Poupin, R. Maache, L. Pirault-Roy, R. Brahmi, C. T. Williams, Appl. Catal. A, 2014, 475, 363-370.

[53] M. Shirai, K. Aoki, K. Torii, M. Arai, Appl. Catal. A, 1999, 187, 141-146.

[54] X. Kong, Y. Zhu, H. Zheng, X. Li, Y. Zhu, Y. W. Li, ACS Catal., 2015, 5, 5914-5920.

\section{催化剂制备方法对用于腈加氢制饱和胺的负载型 $\mathrm{Ni}$ 催化剂性能的影响}

\section{J. Segobia, A. F.Trasarti, C. R. Apesteguía *}

Catalysis Science and Engineering Research Group (GICIC), INCAPE, UNL-CONICET, CCT Conicet- Paraje El Pozo, Santa Fe, 阿根廷

摘要: 采用浸渍法 $\left(\mathrm{Ni}_{\mathrm{SiO}} / \mathrm{SiO}_{2}-\mathrm{I}\right)$ 或氨法 $\left(\mathrm{Ni} / \mathrm{SiO}_{2}-\mathrm{A}\right)$ 制备了硅胶负载的 $\mathrm{Ni}$ 催化剂, 考察了它们和 $\mathrm{Ni} / \mathrm{SiO}_{2}-\mathrm{Al}_{2} \mathrm{O}_{3}-\mathrm{I}$ 样品催化丁腈液 相加氢制备饱和胺反应性能. $\mathrm{Ni} / \mathrm{SiO}_{2}-\mathrm{I}$ 是非酸性催化剂, 含有大的 $\mathrm{Ni}^{0}$ 颗粒, 与载体相互作用较弱; 而 $\mathrm{Ni} / \mathrm{SiO}_{2}-\mathrm{A}$ 中含有低还 原度的 $\mathrm{Ni}$-层状硅酸盐, 存在 $\mathrm{Ni}^{2+}$ 物种, 因而是酸性催化剂. 在 $\mathrm{Ni} / \mathrm{SiO}_{2}-\mathrm{I}$ 催化剂上反应产物基本上是丁胺 $(80 \%)$, 副产物仅为 二丁胺. 相反, 以 $\mathrm{Ni} / \mathrm{SiO}_{2}-\mathrm{A}$ 为催化剂时, 得到二丁胺(49\%)和三丁胺(45\%)的混合物, 而丁胺的生成活性几乎完全得到抑制. 对于 $\mathrm{Ni} / \mathrm{SiO}_{2}-\mathrm{A}$ 催化剂, 丁胺强吸附在邻近 $\mathrm{Ni}^{0}$ 原子的表面酸性位上, 在反应过程中不能扩散到液相中, 从而促进了吸附的丁 基亚胺/丁胺物种之间缩合生成更高级的胺类, 因此造成选择性生成伯胺和仲胺.

关键词: 腈加氢; 饱和胺; 负载型Ni催化剂; 催化剂制备; 镍-层状硅酸盐类

收稿日期: 2018-10-03. 接受日期: 2018-10-12. 出版日期: 2019-11-05.

*通讯联系人. 电话: +54-342-4511370; 电子信箱: capesteg@fiq.unl.edu.ar 本文的电子版全文由Elsevier出版社在ScienceDirect上出版(http://www.sciencedirect.com/science/journal/18722067). 